\title{
Characterisation of mucosal lymphoid aggregates in ulcerative colitis: immune cell phenotype and $\mathrm{TcR}-\gamma \delta$ expression
}

\author{
M M-W Yeung, S Melgar, V Baranov, Å Öberg, Å Danielsson, S Hammarström, \\ M-L Hammarström
}

\begin{abstract}
Background and aims-A histopathological feature considered indicative of ulcerative colitis (UC) is the so-called basal lymphoid aggregates. Their relevance in the pathogenesis of $U C$ is, however, unknown. We have performed a comprehensive analysis of the immune cells in these aggregates most likely corresponding to the lymphoid follicular hyperplasia also described in other colitides. Methods-Resection specimens of UC and normal colon were analysed by immunomorphometry, immunoflow cytometry, and immunoelectron microscopy, using a
\end{abstract} large panel of monoclonal antibodies.

Results-(1) In all cases of UC, colonic lamina propria contained numerous basal aggregates composed of lymphocytes, follicular dendritic cells, and CD80/B7.1 positive dendritic cells. (2) $\mathrm{CD}^{+} \mathrm{CD}^{-} 8^{-} \alpha \beta$ $T$ cells and $B$ cells were the dominant cell types in the aggregates. (3) The aggregates contained a large fraction of cells that are normally associated with the epithelium: that is, $\gamma \delta \mathrm{T}$ cells $\left(11\right.$ (7)\%) and $\alpha_{\mathrm{E}} \beta_{7}^{+}$cells (26 (13)\%). The $\gamma \delta$ T cells used $V \delta 1$ and were $\mathrm{CD}^{-} \mathrm{CD}^{-}$. Immunoelectron microscopy analysis demonstrated $\mathrm{TcR}-\gamma \delta$ internalisation and surface downregulation, indicating that the $\gamma \delta$ T cells were activated and engaged in the disease process. (4) One third of cells in the aggregates expressed the antiapoptotic protein bcl-2. Conclusions-Basal lymphoid aggregates in UC colon are a consequence of anomalous lymphoid follicular hyperplasia, characterised by abnormal follicular architecture and unusual cell immunophenotypes. The aggregates increase in size with severity of disease, and contain large numbers of apoptosis resistant cells and activated mucosal $\gamma \delta \mathrm{T}$ cells. The latter probably colonise the aggregates as an immunoregulatory response to stressed lymphocytes or as a substitute for defective $T$ helper cells in B cell activation. $\gamma \delta T$ cells in the aggregates may be characteristic of UC.

(Gut 2000;47:215-227)

Keywords: basal lymphoid aggregates; ulcerative colitis; T cell receptor $\gamma \delta$; immunomorphology

Department of Immunology,

Umeå University, S-901 85

Umeå, Sweden. Email:

Marie-Louise.Hammarstrom@

climi.umu.se.

Accepted for publication 8 February 2000

Ulcerative colitis (UC) is a large intestine restricted, chronic inflammatory disease of unknown aetiology and pathogenesis. However, there are indications that immune mechanisms play an important role in the pathogenesis of the disease, for example immunosuppressive drugs have therapeutic effects. ${ }^{1-3}$ It has been suggested that UC is caused by failure to maintain homeostasis towards normal gut microbial flora, leading to an uncontrolled immune response to one or a few normally occurring gut constituents. ${ }^{45}$ The inflammation may be perpetuated by an autoimmune response against colonic antigens initiated by cross reactive luminal antigens. Indeed, in 1959 it was shown that autoantibodies directed against colonic components were present in the serum of UC patients. ${ }^{6}$ Later, immunological cross reactivity between certain microbial antigens and colonic tissue antigens was demonstrated using UC patient sera. Recently, Duchmann and colleagues ${ }^{8}$ demonstrated that tolerance exists towards resident intestinal flora but is broken in active inflammatory bowel disease (IBD). Moreover, it was shown that autoantibodies of immunoglobulin G (IgG) directed against intracellular components of epithelial cells, ${ }^{9}{ }^{10}$ antineutrophil cytoplasmic antibodies, ${ }^{11}$ as well as antibodies directed against intestinal bacteria ${ }^{12}$ are produced in the colonic tissue of UC patients. Halstensen and colleagues ${ }^{13}$ noted deposition of IgG1 and complement factors on the apical surface of epithelial cells in areas of UC colon with active disease.

A role for $\mathrm{T}$ lymphocytes in IBD became apparent through work with genetically manipulated mice. $\mathrm{T}$ cell receptor $\alpha(\mathrm{TcR}-\alpha)$ chain and TcR- $\beta$ chain deficient mice lacking the majority of mature $\alpha \beta \mathrm{T}$ cells develop an IBD-like disease. ${ }^{14}$ Similarly, mice with aberrant thymus selection processes (for example, major histocompatibility complex (MHC) class II gene deficient mice ${ }^{14}$ and transgenic mice with human cluster of differentiation 3 (CD3) $\varepsilon$ chain transplanted with normal F1 bone marrow cells ${ }^{15}$ ) also develop IBD-like symptoms. Disruption of certain cytokine genes, such as interleukin-2 (IL-2), IL-10, and occasionally transforming growth factor $\beta,{ }^{16-18}$ as well as of the signal protein $G$ subunit

Abbreviations used in this paper: UC, ulcerative colitis; Ig, immunoglobulin; IBD, inflammatory bowel disease; TcR, T cell receptor; MHC, major histocompatibility complex; IL, interleukin; mAb, monoclonal antibody; PBS, phosphate buffered saline; BSA, bovine serum albumin; FDC, follicular dendritic cells; IEL, intraepithelial lymphocytes; LPL, lamina 
Table 1 Clinical data of ulcerative colitis patients in the study

\begin{tabular}{|c|c|c|c|c|c|}
\hline Patient ID & $\operatorname{Sex}$ & Age (y) & $\begin{array}{l}\text { Duration of } \\
\text { disease }(y)\end{array}$ & Extent of disease & Treatment during 4 weeks prior to colectomy \\
\hline \multicolumn{6}{|c|}{ Severely diseased colonic tissue } \\
\hline UC 50 & M & 65 & 24 & Total colitis & None \\
\hline UC64 & M & 31 & 18 & Total colitis & Prednisolone $20 \mathrm{mg}$ daily, metronidazole $800 \mathrm{mg}$ daily \\
\hline UC 68 & M & 30 & 2 & Total colitis & Prednisolone $20 \mathrm{mg}$ daily, 5-ASA \\
\hline UC 69 & $\mathrm{~F}$ & 45 & 0.2 & Total colitis & Prednisolone $30 \mathrm{mg}$ daily, 5-ASA \\
\hline UC 72 & M & 22 & 1.5 & Total colitis & Prednisolone iv, azathioprin $100 \mathrm{mg}$ daily \\
\hline UC 83 & $\mathrm{~F}$ & 27 & 0.3 & Total colitis & Prednisolone iv \\
\hline UC94 & $\mathrm{F}$ & 40 & 5 & Total colitis & Prednisolone $10 \mathrm{mg}$ daily \\
\hline UC105 & $\mathrm{F}$ & 19 & 7 & Total colitis & Prednisolone $20 \mathrm{mg}$ daily, azathioprin $100 \mathrm{mg}$ daily, 5-ASA \\
\hline UC117 & M & 32 & 18 & Total colitis & Prednisolone $40 \mathrm{mg}$ daily, 5-ASA \\
\hline UC143 & M & 81 & 8 & Total colitis & Prednisolone $40 \mathrm{mg}$ daily, 5-ASA \\
\hline UC152 & M & 38 & 0.5 & Left sided colitis & Prednisolone $20 \mathrm{mg}$ daily, azathioprin $100 \mathrm{mg}$ daily, 5-ASA \\
\hline \multicolumn{6}{|c|}{ Moderately diseased colonic tissue } \\
\hline UC 55 & $\mathrm{~F}$ & 30 & 4 & Total colitis & None \\
\hline UC 82 & $\mathrm{M}$ & 27 & 5 & Severe left sided colitis & Prednisolone $15 \mathrm{mg}$ daily, 5-ASA \\
\hline UC86 & M & 29 & 2.8 & Total colitis & Prednisolone iv \\
\hline UC89 & $\mathrm{F}$ & 21 & 7 & Total colitis & Prednisolone $15 \mathrm{mg}$ daily, azathioprin $100 \mathrm{mg}$ daily \\
\hline
\end{tabular}

M, male; F, female.

Gai2 $2{ }^{19}$ also causes inflammation of the gut. In all of these animal models $\mathrm{T}$ cell dependent regulatory systems are disrupted. The disease in IL-2 deficient mice was limited to the colon and in this respect resembled human UC. Most interestingly, IL-2 deficient mice did not develop colonic inflammation when kept under germ free conditions. ${ }^{16}$ Thus failure to maintain homeostasis with the gut flora due to malfunctioning $\mathrm{T}$ cells is an important component for onset of disease in these mice.

Therapeutic effects are achieved in corticosteroid resistant UC patients by cyclosporin, a drug considered to act selectively on $\mathrm{T}$ helper function, ${ }^{3}$ suggesting that $\mathrm{T}$ cells also contribute to the disease process in UC in humans.

Previous reports, based on colonic biopsies, have described several histopathological features highly characteristic of IBD, particularly UC and Crohn's disease. ${ }^{20-22}$ One of these features is the so-called basal lymphoid aggregates which represent large confluent nodular clusters of lymphocytes located between the bases of the crypts and the submucosa. These structures were suggested to be significant discriminators of UC. ${ }^{20-22}$ It seems likely that the aggregates histologically correspond to lymphoid follicular hyperplasia described originally in ulcerative proctitis and later in a variety of inflammatory colitides such as diversion colitis, lymphoid follicular proctitis, Crohn's colitis, diverticulitis, and adjacent to colon cancer. ${ }^{23}$ We argued that analysis of the immune cells in the aggregates in UC might shed light on the pathogenesis of the disease and perhaps also provide useful information that may help in the differential diagnosis of IBD in the future.

Surprisingly, there are no previous studies describing the immune cells in the basal lymphoid aggregates of UC patients using well characterised monoclonal antibodies (mAbs) directed against leucocyte and activation markers. Hence we performed an in depth analysis of the distribution and frequency of leucocyte populations and lymphocyte subpopulations in the aggregates of resected colonic samples from UC patients in comparison with normal mucosal lymphoid follicles of colon from patients with no history of IBD.

\section{Methods}

TISSUE

Sigmoid colon specimens were obtained from patients undergoing bowel resection for UC ( $n=15$; three analysed only by flow cytometry). Table 1 gives the clinical characteristics of the UC patients. Control samples were obtained from 10 male and five female patients aged 58-81 years (median 69) with colon cancer $(n=12)$, severe constipation $(n=1)$, diverticulosis $(n=1)$, and rectal prolapse $(n=1)$. Intestinal control samples were taken distant to any macroscopically detectable lesion. All patients received a single intravenous dose of antibiotics two hours before surgery. None of the control patients was or had been subjected to radiotherapy or chemotherapy, longstanding antibiotic medication, or steroid treatment.

mAbs

Characteristics of mAbs used are listed in table 2 .

\section{ISOLATION OF LEUCOCYTES FROM COLONIC}

TISSUE

Lamina propria leucocytes (LPL) were isolated using the following procedure: firstly, intraepithelial lymphocytes (IEL) were removed according to a procedure established previously for isolation of IEL from normal intestine. ${ }^{24}$ LPL were obtained from IEL depleted tissue pieces by treatment with $72.5 \mathrm{U} / \mathrm{ml}$ of collagenase type IV (Worthington, Freehold, New Jersey, USA) in neat, heat inactivated human $\mathrm{AB}^{+}$serum with vigorous shaking at $37^{\circ} \mathrm{C}$ for 30 minutes followed by passage through a stainless steel sieve. Cells were thereafter suspended in $66.7 \%$ Percoll (Pharmacia, Uppsala, Sweden), overlaid with a gradient of $50 \%, 44 \%$, and $20 \%$ Percoll and Tris buffered Hank's balanced salt solution and centrifuged. Leucocytes were enriched in the interfaces between $66.7 \%$ and $50 \%$ Percoll (high density leucocytes) and between $50 \%$ and $44 \%$ Percoll (low density leucocytes). Contaminating epithelial cells were removed by incubation with goat antimouse IgG coupled magnetic beads (Dynabeads M-450, Dynal, Norway) charged with mAb BerEP4 followed by separation with a magnet. High density leucocytes constituted 
Table 2 Monoclonal antibodies ( $m A b)$ used in this study

\begin{tabular}{|c|c|c|c|c|}
\hline Marker & mAb/clone & Isotype & Main reactivity & Source \\
\hline $\mathrm{TcR}-\alpha \beta$ & $\beta F 1 / 8 \mathrm{~A} 3$ & IgG1 & Monomorphic determinant of the $\beta$ chain of TcR- $\alpha \beta$ & T cell Diagnostics, Cambridge, MA, USA \\
\hline $\mathrm{TcR}-\alpha \beta$ & $\alpha \mathrm{F} 1 / 3 \mathrm{~A} 8$ & IgG2a & Monomorphic determinant of the $\alpha$ chain of TcR- $\alpha \beta$ & $\mathrm{T}$ cell Diagnostics \\
\hline $\mathrm{TcR}-\alpha \beta$ & BMA031 & $\operatorname{IgG} 2 b$ & Monomorphic determinant on the TcR- $\alpha \beta$ complex & $\mathrm{T}$ cell Diagnostics \\
\hline $\mathrm{TcR}-\gamma \delta$ & TCR $\delta 1 / 5 . A 6 . E 9$ & IgG1 & Monomorphic determinant of the $\delta$ chain of TcR- $\gamma \delta$ & T cell Diagnostics \\
\hline $\mathrm{TcR}-\gamma \delta$ & Immu510 & IgG1 & Monomorphic determinant of the $\delta$ chain of TcR- $\gamma \delta$ & Immunotech, Marseilles, France \\
\hline $\mathrm{TcR}-\gamma \delta$ & $\delta \mathrm{TCS} 1 / \mathrm{TS}-1$ & IgG1 & $\mathrm{V} \delta 1-\mathrm{J} \delta 1 / \mathrm{J} \delta 2$ encoded determinant & T cell Diagnostics \\
\hline $\mathrm{TcR}-\gamma \delta$ & $\delta \mathrm{V} 1(\mathrm{a}) / \mathrm{TS} 8$ & IgG1 & V $\delta 1$ encoded determinant & T cell Diagnostics \\
\hline TcR- $\gamma \delta$ & $15 \mathrm{D}$ & IgG1 & V $\delta 2$ encoded determinant & T cell Diagnostics \\
\hline $\mathrm{TcR}-\gamma \delta$ & P11.5B & IgG1 & V83 encoded determinant & Immunotech \\
\hline CD3 & UCHT1 & IgG1 & $\mathrm{T}$ cells and subsets of thymocytes & Dakopatts, Glostrup, Denmark \\
\hline CD3 & SK7 & IgG1 & $\mathrm{T}$ cells and subsets of thymocytes & Becton-Dickinson, Mountain View, CA, USA \\
\hline $\mathrm{CD} 4$ & MT310 & IgG1 & MHC class II restricted T cells & Dakopatts \\
\hline CD8 & DK25 & IgG1 & MHC class I restricted T cells & Dakopatts \\
\hline CD19 & HD37 & IgG1 & $\mathrm{B}$ cells & Dakopatts \\
\hline CD20 & L-26 & IgG2a & $\mathrm{B}$ cells & Dakopatts \\
\hline $\mathrm{CD} 22$ & $4 \mathrm{~KB} 128$ & IgG $2 b$ & $\mathrm{~B}$ cells & Dakopatts \\
\hline CD14 & МФР6 & IgG2b & Monocytes/macrophages & Becton-Dickinson \\
\hline CD15 & C3D-1 & $\operatorname{IgM}$ & Granulocytes & Dakopatts \\
\hline CD68 & EBM11 & IgG1 & Tissue macrophages, cytolytic lymphocytes & Dakopatts \\
\hline CD57 & NC-1 & $\operatorname{IgM}$ & NK cells and subsets of $T$ cells & Immunotech \\
\hline CD1a & $\mathrm{NA} 1 / 34$ & IgG2a & Thymocytes, Langerhans cells, interdigitating cells & Dakopatts \\
\hline CD45 & $2 \mathrm{~B} 11$ and $\mathrm{PD} 7 / 26$ & IgG1 & Leucocytes & Dakopatts \\
\hline $\mathrm{CD} 45 \mathrm{RO}$ & UCHL-1 & IgG2a & Activated and primed $\mathrm{T}$ cells, thymocytes & Dakopatts \\
\hline CD 45RA & L28 & IgG1 & Resting and naive $\mathrm{T}$ cells & Becton-Dickinson \\
\hline CD103 & HML-1/2G51 & $\operatorname{IgG} 2 \mathrm{a}$ & $\alpha$ chain of the $\alpha_{\mathrm{E}} \beta_{7}$ integrin, mucosal lymphocytes & Immunotech \\
\hline CD28 & CD28.2 & IgG1 & Subpopulations of $\mathrm{T}$ cells & Immunotech \\
\hline CD80 & BB-1 & $\operatorname{IgM}$ & Antigen presenting cells & Serotec, Oxford, UK \\
\hline HLA-DR & DK22 & IgG2a & Monomorphic determinant of HLA-DR & Dakopatts \\
\hline HLA-DQ & SPVL3 & $\mathrm{IgG} 2 \mathrm{a}$ & Monomorphic determinant of HLA-DQ & Immunotech \\
\hline $\operatorname{IgM}$ & $\mathrm{R} 1 / 69$ & IgG1 & Human IgM & Dakopatts \\
\hline IgG & TM15 & IgG1 & Human IgG & The Binding site, Birmingham, UK \\
\hline IgA & $6 \mathrm{E} 2 \mathrm{C} 1$ & IgG1 & Human IgA & Dakopatts \\
\hline $\mathrm{bcl}-2$ & 124 & IgG1 & Antiapoptosis protein & Dakopatts \\
\hline Epithelial antigen & BerEP4 & IgG1 & Human epithelial cells & Dakopatts \\
\hline $\begin{array}{l}\text { Follicular dendritic } \\
\text { cells }\end{array}$ & $\mathrm{Ki}-\mathrm{M} 4$ & IgG2a & $\begin{array}{l}\text { Follicular dendritic cells (accesory B cell macrophages) in } \\
\text { lymphoid organs }\end{array}$ & BMA Biomedicals AG, Augst, Switzerland \\
\hline $\begin{array}{l}\text { Follicular dendritic } \\
\text { cells }\end{array}$ & CNA.42 & $\operatorname{Ig} M$ & $\begin{array}{l}\text { Non-lineage restricted antigen expressed on follicular } \\
\text { dendritic cells }\end{array}$ & Dakopatts \\
\hline $\begin{array}{l}\text { Follicular dendritic } \\
\text { cells }\end{array}$ & $\mathrm{R} 4 / 23$ (DRC-1) & $\operatorname{IgM}$ & Dendritic reticulum cells present in lymphoid follicles & Dakopatts \\
\hline Negative control & DAK-G01 & IgG1 & A niger glucose oxidase & Dakopatts \\
\hline Negative control & DAK-G05 & IgG2a & A niger glucose oxidase & Dakopatts \\
\hline Negative control & DAK-G09 & $\operatorname{IgG} 2 \mathrm{~b}$ & $A$ niger glucose oxidase & Dakopatts \\
\hline Negative control & DAK-G08 & $\operatorname{IgM}$ & $A$ niger glucose oxidase & Dakopatts \\
\hline
\end{tabular}

$68(10) \%$ of all CD $45^{+}$cells in the preparations and low density leucocytes $32(10) \%(n=4)$. High and low density leucocytes were analysed separately by immunoflow cytometry. CD19/ $20 / \mathrm{CD} 22^{+}$cells and CD $4^{+} \mathrm{TcR}-\alpha \beta^{+}$cells constituted the majority of cells in the low density fraction while all lymphocyte subpopulations were present in the high density fraction. The composition of the total LPL was calculated on the basis of cell yields and the proportion of surface marker expressing cells in both fractions. With the exception of fig 4, all results from the immunoflow cytometry analysis are given as calculated percentage of marker positive cells in the total LPL preparation.

IMMUNOFLOW CYTOMETRY

Single and two colour staining of isolated cells were performed as described previously. ${ }^{25}$

IMMUNOHISTOCHEMISTRY

Fresh tissue samples were rinsed with cold phosphate buffered saline (PBS), snap frozen in isopentane precooled in liquid nitrogen, and stored at $-70^{\circ} \mathrm{C}$. Thick cryosections $(5-7 \mu \mathrm{m})$ were stained by one of the following five immunohistochemical methods.

For immunoperoxidase staining of most surface markers the sections were fixed for five minutes in acetone at $-20^{\circ} \mathrm{C}$, air dried for 15 minutes, and blocked for endogenous peroxidase activity by incubation in PBS ( $\mathrm{pH}$ 7.2) containing $0.03 \% \mathrm{H}_{2} \mathrm{O}_{2}$ and $2 \mathrm{mM} \mathrm{NaN}_{3}$ at $37^{\circ} \mathrm{C}$ for 60 minutes. Thereafter the sections were incubated with $0.2 \%$ bovine serum albumin (BSA) in PBS, followed by incubation with $\mathrm{mAb}$ for 60 minutes at room temperature, and finally were incubated with horseradish peroxidase conjugated $\mathrm{F}\left(\mathrm{ab}^{\prime}\right)_{2}$ fragments of sheep antimouse Ig (Amersham, Buckinghamshire, $\mathrm{UK}$ ) for 60 minutes at room temperature. Sections were developed with $0.05 \%$ 3,3'diaminobenzidine tetrahydrochloride and $0.03 \% \mathrm{H}_{2} \mathrm{O}_{2}$ in $0.05 \mathrm{M}$ Tris $\mathrm{HCl}$ buffer $(\mathrm{pH}$ 7.6) and counterstained with Mayer's haematoxylin or methyl green.

In accordance with our previous studies, unfixed tissue was used to make visible TcR- $\gamma \delta$ cells. ${ }^{25}{ }^{26}$ Immunoperoxidase staining of $\gamma \delta \mathrm{T}$ cells was performed on unfixed sections followed by blocking with PBS containing $0.2 \%$ BSA. Cells were then incubated with $\mathrm{mAb}$, diluted in PBS containing $0.05 \%$ saponin for 60 minutes at room temperature, washed and fixed for 10 minutes in $1 \%$ paraformaldehyde at room temperature. Thereafter the sections were blocked for endogenous peroxidase activity, incubated with antimouse Ig conjugate, and developed as described above.

For immunoperoxidase staining of immunoglobulin isotypes, sections were fixed for 30 seconds in acetone at $-20^{\circ} \mathrm{C}$, incubated with PBS containing $0.2 \%$ BSA and $0.0005 \%$ saponin, washed and incubated with $\mathrm{mAb}$ in 

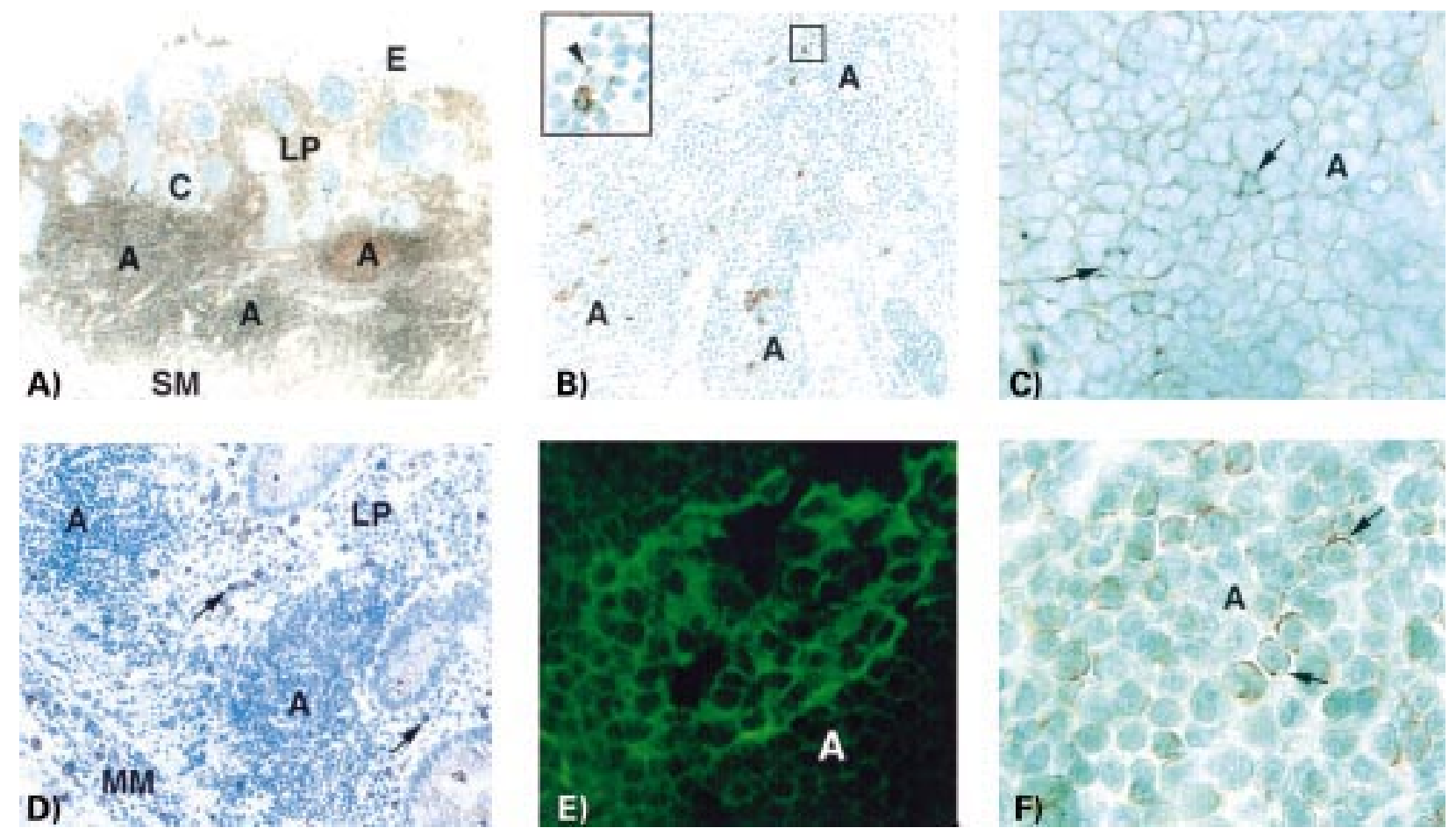

Figure 1 Immunoperoxidase $(A, B, C, D, F)$ and immunofluorescence (E) staining of basal lymphoid aggregates in ulcerative colitis colon. (A) Section stained with anti-CD45 monoclonal antibody ( $m A$ b). Three aggregates (" $A$ ") can be seen in the enlarged lamina propria (LP) in close proximity to the submucosa (SM). Large numbers of scattered CD $45^{+}$cells can also be seen in the lamina propria outside the aggregates. Several deep crypts (" $C$ ") extend into the lamina propria. The number of goblet cells is significantly reduced in cryptal and luminal epithelia (" $E$ ") ( $\times 18)$. (B) Section stained with a mixture of anti-pan $T c R-\gamma \delta m A b s$ (TCR $\delta 1, \delta T C S 1$, and $V \delta 1)$ showing several $\gamma \delta T$ cells scattered throughout the aggregate. Inset: One $\gamma \delta$ T cell with cytoplasmic staining and single cells with dotted staining (arrowhead) ( $\times 55$, inset $\times 220)$. (C) Aggregate ("A") in a section stained with anti- $\alpha_{E} / C D 103$ $m A b$. Cells with membrane staining are frequent. Arrows indicate strongly stained cells ( $\times 220)$. (D) Section stained with anti-CD28 mAb. CD28 expressing cells cannot be detected in the aggregates (" $A$ ") but are frequent in lamina propria (LP) outside the aggregates (arrows). Intraepithelial CD28+ cells are scarce $(\times 32)$. (E) Section stained with anti-CD80 (B7.1) mAb. A dendritic cell network of CD80 positive cells in an aggregate ("A") is seen ( $\times 160)$. (F) Aggregate (" $A$ ") in a section stained with anti-bcl-2 mAb. A high proportion of the cells show cytoplasmic staining for the bcl-2 protein. Arrows indicate typical stained cells (×320). A, aggregate; $C$, crypt; E, luminal epithelium; LP, lamina propria; MM, muscularis mucosae; SM, submucosa.

the presence of $0.0005 \%$ saponin for 60 minutes at room temperature. Finally, the sections were fixed for four minutes in acetone at $-20^{\circ} \mathrm{C}$, blocked for endogenous peroxidase activity, incubated with antimouse Ig conjugate, and developed as described above.

Expression of bcl-2 was analysed in paraformaldehyde fixed tissue using an immunoperoxidase technique described by Pileri and colleagues. ${ }^{27}$ The sections were developed as described above and counterstained with methyl green.

Expression of $\mathrm{TcR}-\gamma \delta$, TcR- $\alpha \beta, \mathrm{CD} 3, \mathrm{CD} 4$, CD8, CD 19/20/22, CD80, and CD45 was also analysed by immunofluorescence. Unfixed sections were blocked with PBS containing $0.2 \% \mathrm{BSA}$, incubated with $\mathrm{mAb}$ for 60 minutes at room temperature, washed, fixed for five minutes in acetone at room temperature, and incubated with fluorescein isothiocyanate conjugated $\mathrm{F}\left(\mathrm{ab} \mathrm{b}_{2}\right.$ fragments of goat antimouse IgG and IgM (Jackson Immunoresearch Laboratories, West Grove, Pennsylvania, USA). Thereafter the sections were counterstained with Evan's blue and mounted in $90 \%$ glycerol in PBS ( $\mathrm{pH}$ 8.0) containing $1 \mathrm{mg} / \mathrm{ml}$ $o$-phenyldiamine as antifading agent.

The final concentration for optimal detection of markers ranged from 2.5 to $30 \mu \mathrm{g} / \mathrm{ml}$ for different mAbs. Sections incubated with isotype and concentration matched irrelevant mAbs served as negative controls, and human palatine tonsils were used as positive controls.
QUANTIFICATION OF THE LYMPHOID AGGREGATES The total number of aggregates per section, total area of lamina propria, and the area occupied by the aggregates were determined in anti-CD45 stained sections using a $4 \times$ objective and the Leica Q500MC computer image analysis system.

QUANTIFICATION OF LEUCOCYTES IN SITU

Morphometry analysis of cells in lymphoid aggregates, solitary follicles, lamina propria outside aggregates/follicles, and the submucosa was performed according to Weibel and colleagues. $^{28}$ A square lattice grid with 121 coarse points was superimposed on the sections using a $40 \times$ objective for immunoperoxidase and a $50 \times$ objective for immunofluorescence stained sections. Positive cells located in the coarse points were counted and expressed as a percentage of the total number of coarse points. Coarse points in empty spaces or outside the compartment under investigation were excluded. Eight to 15 ocular fields were counted for each marker and sample. In the case of the lower number of ocular fields it corresponded to all aggregates in the section. Immunoperoxidase staining was used for all markers except $\mathrm{TcR}-\gamma \delta$. Immunofluorescence gave optimal detection of cells stained by the pan- $\delta$-chain $\mathrm{mAb} \operatorname{TCR} \delta 1$ and was therefore used in morphometric analyses of $\mathrm{TcR}-\gamma \delta^{+}$cells. $^{26}$ 
Table 3 Frequency and area of basal lymphoid aggregates in the colonic mucosa of ulcerative colitis patients

\begin{tabular}{lllll}
\hline Sample ID & $\begin{array}{l}\text { Disease } \\
\text { classification\# }\end{array}$ & $\begin{array}{l}\text { Frequency of } \\
\text { aggregates } \\
(\text { Nolmm })^{*}\end{array}$ & $\begin{array}{l}\text { Mean area of } \\
\text { aggregates } \\
\left(\mathrm{mm}^{2}\right) \dagger\end{array}$ & $\begin{array}{l}\text { \% of lamina propria } \\
\text { occupied by } \\
\text { aggregates } \neq\end{array}$ \\
\hline UC50 & Severe & 1.4 & 0.07 & 17 \\
UC68 & Severe & 4.9 & 0.03 & 20 \\
UC69 & Severe & 1.8 & 0.08 & 18 \\
UC72 & Severe & 1.5 & 0.14 & 30 \\
UC83 & Severe & 2.5 & 0.14 & 45 \\
UC94 & Severe & 2.2 & 0.28 & 43 \\
Mean (SD) & Moderate & $2.4(1.3)$ & $0.12(0.09)$ & $29(13)$ \\
UC55 & 1.3 & 0.13 & 17 \\
UC82 & Moderate & 3.8 & 0.04 & 21 \\
UC89 & Moderate & 1.8 & 0.03 & 7 \\
Mean (SD) & & $2.3(1.3)$ & $0.07(0.05)$ & $15(7)$ \\
\hline
\end{tabular}

\#Severely diseased tissue: samples had flattened epithelium with low numbers of goblet cells, branched crypts and occasional disruptions. Lamina propria was enlarged and contained numerous leucocytes. Crypt abscesses were often seen. Submucosa was enlarged and contained elevated levels of leucocytes. Moderately diseased tissue: samples had intact epithelium with slightly reduced numbers of goblet cells and no branched crypts. Lamina propria contained increased numbers of leucocytes.

${ }^{\star}$ Number of aggregates was counted in an anti-CD45 stained section and the total area of lamina propria in the section was determined by morphometry.

†The area of individual aggregates was determined by morphometry in anti-CD45 stained sections. $\ddagger($ Total area occupied by aggregates/total area of lamina propria) $\times 100$.

IMMUNOELECTRON MICROSCOPY OF TcR- $\gamma \delta^{+}$CELLS Colonic mucosa was fixed in $4 \%$ paraformaldehyde in $0.1 \mathrm{M}$ sodium cacodylate buffer $(\mathrm{pH}$ 7.3) for four hours on ice. The fixed specimens were washed in the same buffer containing $3.5 \%$ sucrose and $0.05 \%$ saponin at $4^{\circ} \mathrm{C}$ overnight, frozen, cut into $15 \mu \mathrm{m}$ thick cryosections, and collected on poly-L-lysine coated Thermanox coverslips (NUNC, Roskilde, Denmark). Thereafter the sections were incubated with a mixture of mAbs TCR $\delta 1, \mathrm{~V} \delta 1$, and $\delta$ TCS 1 diluted in PBS containing $0.05 \%$ saponin for 12 hours at $4^{\circ} \mathrm{C}$, washed, and subsequently incubated with biotinylated $\mathrm{F}\left(\mathrm{ab}^{\prime}\right)_{2}$ fragments of sheep antimouse Ig (Amersham) for five hours at room temperature. Endogenous peroxidase activity was blocked by incubation in $0.02 \mathrm{M}$ PBS containing $2 \mathrm{mM} \mathrm{NaN}_{3}$ and $0.03 \% \mathrm{H}_{2} \mathrm{O}_{2}$ for one hour at $37^{\circ} \mathrm{C}$. Finally, the sections were incubated with peroxidase conjugated streptavidin (Jackson Immunoresearch Lab.) at $4^{\circ} \mathrm{C}$ overnight and developed as described above. The sections were then fixed with $1.33 \% \mathrm{OsO}_{4}$ (Sigma) for one hour, dehydrated in acetone, and flat embedded in a mixture of Epon and Araldite (Fluka, Buchs, Switzerland). Ultrathin sections were examined under a Zeiss EM 900 electron microscope. Sections incubated with irrelevant mouse IgG1 $\mathrm{mAb}$ or with PBS served as specificity controls. Three UC colon samples and two normal colon samples were analysed.

\section{STATISTICAL ANALYSIS}

Values of marker positive cells are expressed as mean (SD). Statistical analyses of differences between UC and normal colon were performed using a two tailed Student's $t$ test assuming unequal variance in the groups. A p value $\leqslant 0.05$ was regarded as statistically significant.

\section{Results}

LEUCOCYTES CONSTITUTE THE MAJOR CELL TYPE IN INFLAMED UC COLON AND DISTRIBUTE DIFFERENTLY IN THE COLONIC MUCOSA OF UC PATIENTS COMPARED WITH CONTROLS Twelve samples of inflamed sigmoid colon from UC patients and 15 samples of apparently normal sigmoid colon from patients with no history of IBD were subjected to phenotypic analysis by immunohistochemistry. Nine of these UC samples were classified as severely diseased. In these the epithelium was flattened with reduced numbers of goblet cells, branched crypts, and occasional ulcerations. Crypt abscesses were common. The lamina propria contained numerous scattered leucocytes as well as basal lymphoid aggregates (fig 1A). Three UC specimens were classified as moderately diseased. In all the epithelium was intact with slightly reduced numbers of goblet cells and no/few branched crypts. The lamina propria contained increased numbers of leucocytes and lymphoid aggregates were present. The morphometric analysis was focused on the aggregates.

The aggregates comprised nodular merging clusters of lymphocytes without typical reactive centres. They were located between the bases of the crypts and the submucosa without apparent contact with the luminal epithelium (fig 1A). However, close proximity between cells in the aggregates and crypt epithelium was often noted (fig 1A, D). The frequency of aggregates (number/area) was similar in moderately and severely diseased tissue, ranging from 1.3 to 4.9 aggregates per $\mathrm{mm}^{2}$ of lamina propria (table 3). However, the area of the lamina propria occupied by the aggregates increased with the severity of the disease and constituted as much as $45 \%$ of the lamina propria in severely diseased colon from some patients (table 3). Normal solitary follicles in control colon were infrequent (less than 0.1 follicle $/ \mathrm{mm}^{2}$ of lamina propria, $\mathrm{n}=8$ ).

Approximately $75 \%$ of cells in the aggregates were leucocytes $\left(74(7) \% \mathrm{CD} 45^{+}\right.$cells $\left.(\mathrm{n}=9)\right)$. The proportion of leucocytes in solitary lymphoid follicles was also high (67 (6)\% CD $45^{+}$cells $\left.(n=8)\right)$. Both values may be underestimates as staining with anti-CD45 $\mathrm{mAb}$ was heterogeneous. This heterogeneous staining may be explained, at least in part, by decreased expression of CD45 on activated B cells.

The number of leucocytes both in the lamina propria outside the aggregates (26 (7)\% CD $45^{+}$cells $\left.(n=4)\right)$ and in the submucosa (8 (2) $\% \mathrm{CD} 5^{+}$cells $(\mathrm{n}=4)$ ) was increased in UC colon compared with normal colon (15 (2)\% $\mathrm{CD} 45^{+}$cells in the lamina propria outside the follicles and $4(2) \% \mathrm{CD} 45^{+}$cells in the submucosa $(n=4))$.

Intraepithelial leucocytes were present in lower frequencies in UC colon compared with normal colon: 28 (7) CD $45^{+}$cells/1000 epithelial cells in severely diseased colonic tissue $(n=4)$ compared with 66 (26) $C D 45^{+}$cells/ 1000 epithelial cells in controls $(n=4, p=0.03)$. IEL were mainly detected within the cryptal epithelium in UC colon, partly due to erosions of the luminal surface epithelium. In normal colon, $>60 \%$ of IEL were located in the luminal epithelium. Thus as the density of IEL is lower in cryptal than in luminal epithelium in normal colon the lower frequency of IEL in UC colon may be explained by the fact that UC colon contains mainly cryptal epithelium. 

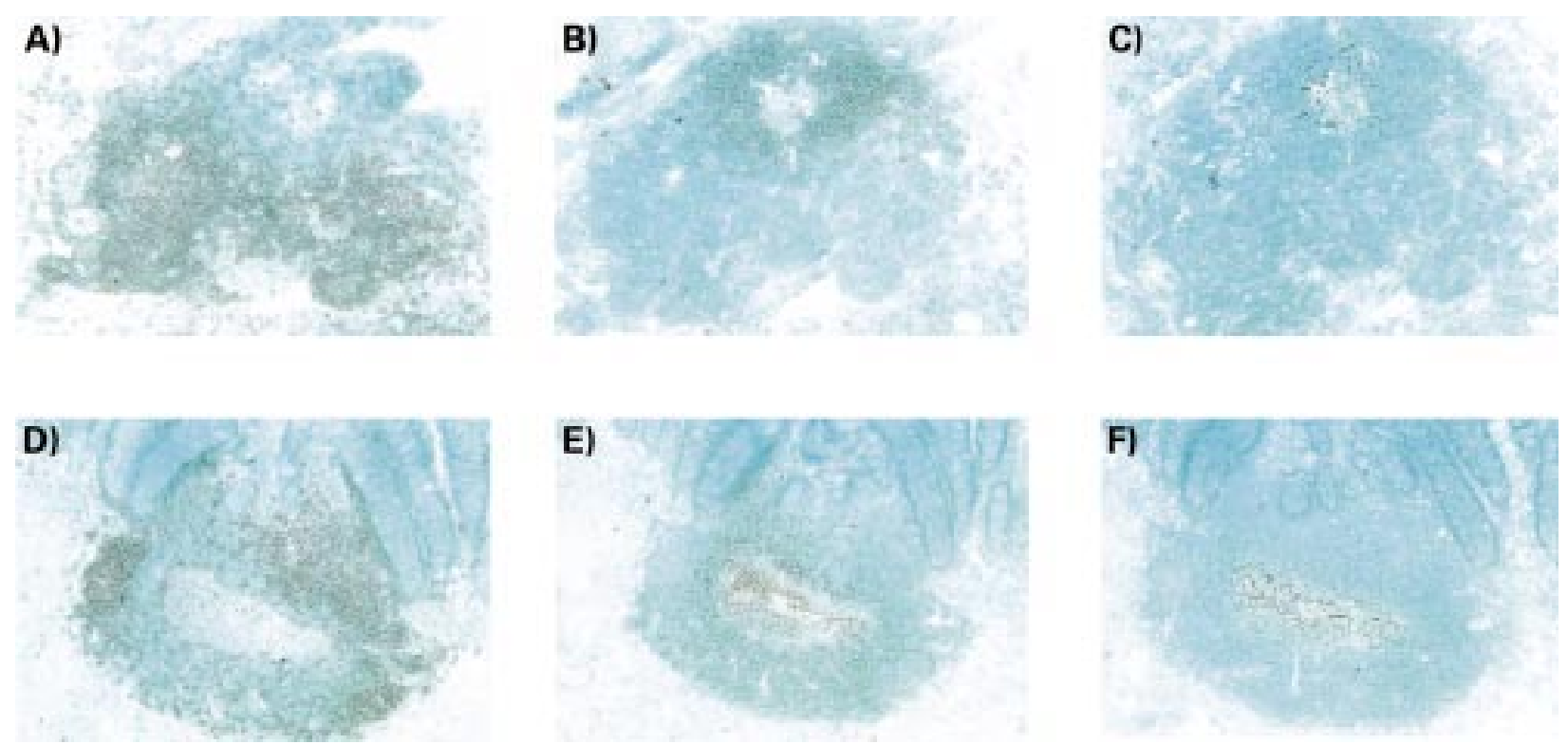

Figure 2 Immunoperoxidase staining of sequential sections of basal lymphoid aggregates in ulcerative colitis colon ( $A$, $B, C$ ) and of solitary follicles in normal colon $(D, E, F)$. (A) Section stained with anti-CD3 $\mathrm{mAb}$ showing an aggregate with numerous positive cells concentrated in two main areas and a few scattered cells in the reciprocal $B$ cell area. (B) The same aggregate as in (A) stained with a mixture of anti-CD19 mAb, anti-CD20 mAb, and anti-CD22 $\mathrm{mAb}$. Positive cells are localised in the area with only a few scattered $C D 3^{+}$cells. (C) The same aggregate as in (A) stained with anti-FDC $m A b \mathrm{Ki}$-M4 showing a follicular dendritic cell network localised to the B cell area. (D) Section of a normal solitary follicle stained with anti-CD3 mAb. $C D 3^{+}$cells are mainly found in three clusters localised in the outer rim of the follicle. (E) The same follicle as in (D) stained with a mixture of anti-CD19 $m A b$, anti-CD20 mAb, and anti-CD22 mAb. Positive cells are localised in the centre of the follicle. Note a central zone of large loosely packed positive cells surrounded by more tightly packed small positive cells. (F) The same follicle as in (D) stained with anti-FDC mAb Ki-M4 showing the follicular dendritic cell network localised to the centre of the $B$ cell area. Original magnifications, $A-F, \times 55$.

AGGREGATES IN THE COLONIC TISSUE OF UC PATIENTS ALMOST EXCLUSIVELY COMPRISE T AND B LYMPHOCYTES

Aggregates were analysed for the presence of the three major types of lymphocytes: $T$ cells (anti-CD3 mAb), B cells (a mixture of anti-CD19, anti-CD20, and anti-CD22 $\mathrm{mAbs}$ ), and NK cells. For analysis of NK cells, anti-CD $57 \mathrm{mAb}$ was chosen as we have previously shown that $\alpha \beta$ and $\gamma \delta \mathrm{T}$ cells expressing the classical NK cell marker CD56 are present in human gut. ${ }^{25}$ Anti-CD15 was used to detect granulocytes, anti-CD14 for blood monocytes/ recently recruited macrophages, and antiCD68 for tissue macrophages. To detect follicular dendritic cells (FDC), three different mAbs were used (table 2). Anti-CD80/B7.1 was used to detect cells with antigen presenting function and anti-CD1a was used as an additional marker for dendritic/Langerhans cells. The results of the immunomorphometric analysis are summarised in fig 3. The two major cell types were $\mathrm{T}$ and $\mathrm{B}$ cells and the sum of $\mathrm{CD}^{+}$cells and CD19/20/22 $2^{+}$cells equalled the number of $\mathrm{CD} 45^{+}$cells in most samples (77 (12)\% compared with 74 (7)\% CD $45^{+}$cells $(n=9)) . T$ and $B$ cells constituted equally large proportions of the cells in the aggregates. The aggregates contained large $\mathrm{T}$ cell areas with no $\mathrm{B}$ cells and reciprocal areas dominated by $\mathrm{B}$ cells with only a few scattered $\mathrm{T}$ cells (fig $2 \mathrm{~A}$, B). Most aggregates consisted of densely packed cells but in some instances limited areas of more loosely packed cells were detected in the $\mathrm{B}$ cell zone. The proportion of B cells was significantly higher in aggregates of severely diseased UC colon compared with moderately diseased tissue (43 (8) v 30 (6); $\mathrm{p}=0.03$ ), suggesting increased importance of $\mathrm{B}$ cells in severe forms of the disease. Solitary follicles in normal colon had a slightly different appearance. The centre of the follicle contained loosely packed large B cells with few if any $T$ cells, surrounded by a zone of both $B$ and $T$ cells and areas in the periphery which contained $\mathrm{T}$ cells only (fig $2 \mathrm{D}, \mathrm{E}$ ).

Follicular dendritic cells were detected in seven of nine UC samples using three different anti-FDC mAbs. No difference in staining patterns was seen between the three mAbs. The positively stained follicular dendritic cells formed a network that was located in the B cell area of the aggregates (fig 2B, C). Although every aggregate contained at least one B cell area, only about $40 \%$ contained an FDC network. FDC networks were never seen in $\mathrm{T}$ cell areas. In normal colon every follicle contained an FDC network which was confined to the B cell area (fig $2 \mathrm{E}, \mathrm{F}$ ). CD80/B7.1 ${ }^{+}$ dendritic cells were also present in the aggregates of UC colon. They were most commonly seen as single dendritic cells surrounded by small $\mathrm{CD} 0^{+}$dots between lymphocytes, presumably cross sections of dendritic protrusions. Occasionally a complete network of $\mathrm{CD}^{+} 0^{+}$cells could be seen (fig $1 \mathrm{E}$ ). This network was located in a $\mathrm{T}$ cell area. No CD $\mathrm{a}^{+}$ cells with a dendritic morphology were detected in the aggregates.

Although the proportion of granulocytes, $\mathrm{CD} 15^{+}$cells, was elevated in most UC samples, such cells were generally located outside the aggregates (fig 3). Numerous tissue macrophages, $\mathrm{CD}^{+} 8^{+}$cells, were present in the lamina propria outside the aggregates. In the aggregates they were scarce and located in the outer rim (fig 3). In normal colon, most CD68 ${ }^{+}$ cells were localised in the proximity of the 


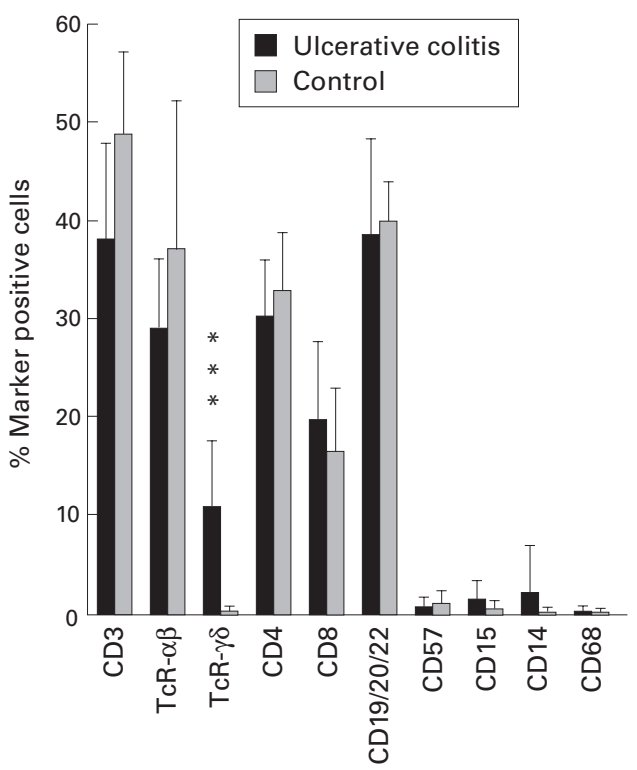

Figure 3 Immunomorphometric analysis of basal lymphoid aggregates in ulcerative colitis (UC) colon and solitary follicles in control colon. Bars represent mean (SD) per cent positive cells of all cells in the aggregate/follicle, as determined by morphometric counting of immunohistochemically stained cryosections. Nine UC colon samples (six severe, three moderate) were counted. Solitary follicles in 6-8 control colon samples were analysed for all markers except $C D 68$, in which case $n=2$. An indirect immunoperoxidase technique was used for staining with anti-CD3, anti-TcR- $\alpha \beta$, anti-CD4, anti-CD8, anti-CD19/CD20/CD22, anti-CD57, anti-CD15, anti-CD14, and anti-CD68 monoclonal antibodies ( $m A b)$. Indirect immunofluorescence was used for staining with anti-TcR- $\gamma \delta m A b .{ }^{\star \star \star} p<0.001$, aggregates in UC compared with solitary follicles in control colon.

luminal epithelium. ${ }^{29}$ Aggregates with significant numbers of CD $14^{+}$cells were seen in only two samples. These samples also had a high frequency of $\mathrm{CD} 14^{+}$cells in the submucosa (that is, $\approx 3.5 \% \mathrm{CD} 14^{+}$cells compared with $\approx 1 \% \mathrm{CD} 14^{+}$cells in other UC colon samples and control colon). Furthermore, CD $14^{+}$cells were concentrated near blood vessels, suggesting ongoing invasion of monocytes. There was no obvious clinical parameter that could explain why monocyte invasion had occurred, particularly in these two samples. NK cells, $\mathrm{CD} 57^{+}$cells, were rare both in UC and normal colon tissue and were only occasionally detected in aggregates (fig 3).

The lymphoid aggregates in UC colon did not differ significantly from solitary follicles in normal colon with respect to numbers of $\mathrm{T}$ cells, B cells, macrophages/monocytes, granulocytes, and NK cells (fig 3). Moreover, an FDC network located in the B cell zone was

Table $4 V \delta$ gene usage of $T c R-\gamma \delta^{+}$cells in lamina propria leucocytes isolated from the colon of ulcerative colitis (UC) patients, as determined by immunoflow cytometry

\begin{tabular}{lllll}
\hline \multirow{4}{*}{ Specificity of $m A b$} & UC patient & & \\
\cline { 2 - 5 } & UC83 & UC86 & UC94 & UC105 \\
\hline V $\delta 1-\mathrm{J} \delta 1 / \mathrm{J} \delta 2^{\mathrm{a}}$ & $71^{\mathrm{b}}$ & 92 & 93 & 87 \\
V82 & 27 & 8 & 7 & 8 \\
V83 & 2 & 0 & 0 & 5 \\
\hline
\end{tabular}

$\star$ Details for individual patients are given in table 1 .

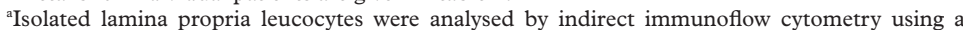
monoclonal antibody $(\mathrm{mAb})$ with the indicated specificity. For details of mAbs see table 2 .

${ }^{\mathrm{b}}$ Per cent cells stained by mAb with the indicated $\mathrm{V} \delta$ gene specificity of all $\mathrm{TcR}-\gamma \delta^{+}$cells in the cell preparation. seen in both types of structures. However, the aggregates lacked a typical germinal centre-like $\mathrm{B}$ cell zone with loosely packed B cells which is seen in normal solitary follicles. Moreover, the aggregates in UC colon occupied up to $45 \%$ of the lamina propria.

AGGREGATES IN UC COLON ARE COLONISED BY $\gamma \delta$ T CELLS

A surprisingly large number of the cells in the aggregates were $\gamma \delta \mathrm{T}$ cells $\left(11(7 \%) \mathrm{TcR}-\gamma \delta^{+}\right.$ cells $(n=9)$ ) (fig $1 B, 3)$. In contrast, almost no $\gamma \delta \mathrm{T}$ cells were detected in follicles of normal colon $\left(0.3 \quad(0.3) \% \quad \mathrm{TcR}-\gamma \delta^{+}\right.$cells $\quad(\mathrm{n}=8)$ $(\mathrm{p}<0.001)$ ) (fig 3). The number of $\mathrm{TcR}-\gamma \delta^{+}$ cells in the aggregates increased with the severity of the disease. The ratio of TcR- $\alpha \beta^{+}$cells to $\mathrm{TcR}-\gamma \delta^{+}$cells in the aggregates was $2.4(0.9)$ in severely diseased UC samples $(n=6)$ but varied from 1.3 to 42 in moderately diseased samples $(n=3)$ and was $>300$ in normal colon follicles. In five samples the frequencies of $\gamma \delta \mathrm{T}$ cells both in aggregates and in lamina propria outside the aggregates were determined. In the aggregates, the frequency of TcR- $\gamma \delta^{+}$cells was 3.9 (2.5) times higher than outside the aggregates. $\mathrm{TcR}-\gamma \delta^{+}$cells in the aggregates mainly expressed $\mathrm{V} \delta 1$ while most cells using V $\delta 2$ were found outside the aggregates. The total LPL fraction was analysed for $V \delta$ gene usage by immunoflow cytometry on isolated cells. In agreement with the immunohistochemical results, $86(10) \%$ of the TcR- $\gamma \delta^{+}$cells expressed $V \delta 1$ while the remaining cells expressed V $\delta 2$ (table 4). In line with the ultrastructural analysis of $\gamma \delta^{+} \mathrm{T}$ cells (see below), staining of TcR $-\gamma \delta^{+}$cells often showed a patchy or spotted appearance on immunohistochemistry (fig 1B, inset) and displayed a relatively low fluorescence intensity in immunoflow cytometry (fig 4). Because of the heterogeneous staining pattern for $\mathrm{TcR}-\gamma \delta$, the number of $\gamma \delta^{+} \mathrm{T}$ cells may be an underestimate. Two colour immunoflow cytometry analysis of isolated LPL showed that almost all $\gamma \delta^{+} \mathrm{T}$ cells expressed CD45R0. Up to $15 \%$ of the $\gamma \delta^{+} \mathrm{T}$ cells expressed CD8 but most $\gamma \delta^{+} \mathrm{T}$ cells were $\mathrm{CD} 4 / \mathrm{CD} 8$ double negative.

$\mathrm{CD} 4^{+} \mathrm{CD} 28^{-} \alpha \beta$ T CELLS CONSTITUTE THE MAJOR T CELL SUBTYPE IN THE AGGREGATES

The majority of $\mathrm{T}$ cells in the aggregates expressed TcR- $\alpha \beta$ and the proportion of $\mathrm{CD} 4^{+}$ cells was higher than the proportion of $\mathrm{CD}^{+}$ cells (fig 3) with an average CD4/CD8 ratio of $1.7(0.7)(n=8)$. The dominance of $\mathrm{CD}^{+}$cells was even more pronounced when isolated LPL were analysed (fig 4). Two colour immunoflow cytometry analysis of LPL showed that almost all $\mathrm{CD}^{+}$cells expressed TcR- $\alpha \beta$ (data not shown). $\mathrm{CD}^{+}$cells were found only in the $\mathrm{T}$ cell area of the aggregates while $\mathrm{CD} 4^{+}$cells were present both in the $\mathrm{T}$ cell area and scattered in the B cell area. In several samples the sum of $\mathrm{CD} 4^{+}$and $\mathrm{CD} 8^{+}$cells exceeded the number of $\mathrm{CD}^{+}$cells and/or $\mathrm{TcR}^{+}$cells. This probably reflects underestimation of $\mathrm{T}$ cells because of the low level expression of the CD3/ TcR complex rather than the presence of CD4/CD8 double positive cells as only 2.4 

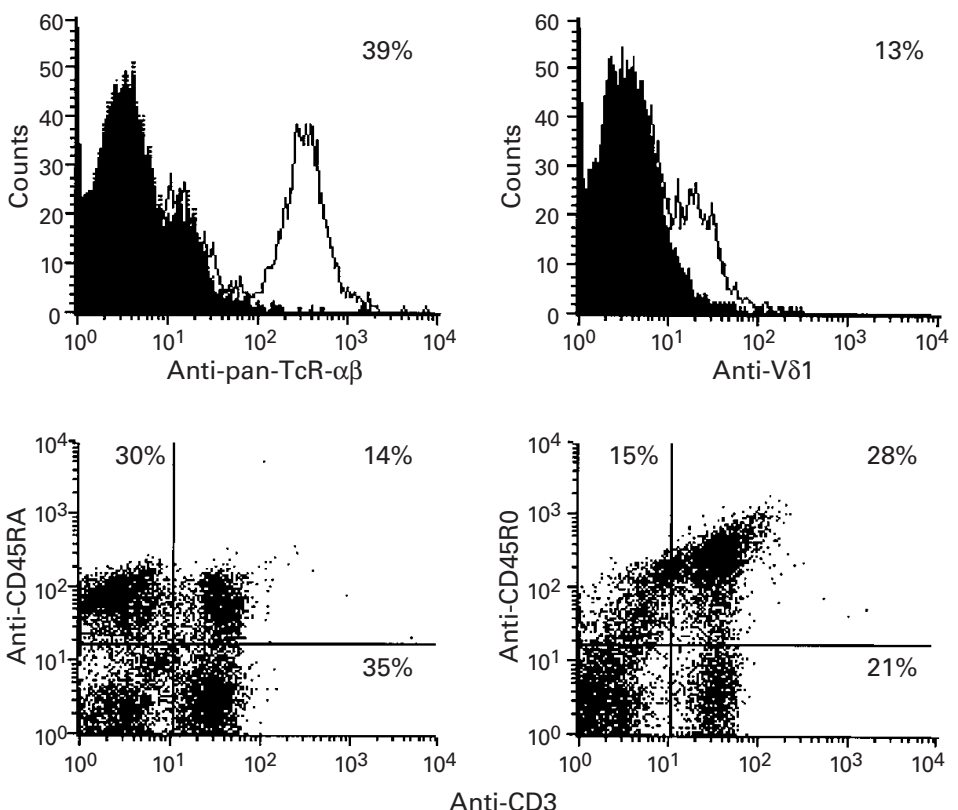

Anti-CD3

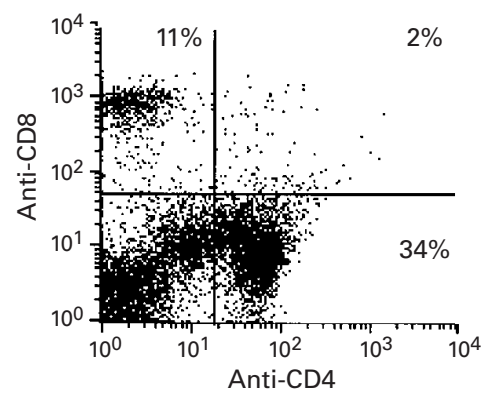

Figure 4 Flow cytometry analysis of high density lamina propria leucocytes isolated from one ulcerative colitis (UC) colon sample. Cells were stained with phycoerythrin labelled

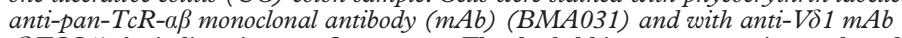
(OTCS1) for indirect immunofluorescence. The shaded histograms superimposed on the graphs show the negative controls. Expression of CD45RO and CD45RA by T cells was assayed using PerCP labelled anti-CD $\mathrm{mAb}$ (SK7) and FITC labelled anti-CD45RA $m A b$ (L28), and anti-CD45RO $m A b$ (UCHL-1), respectively. CD4 and CD8 positive cells were determined by two colour immunoflow cytometry using FITC labelled anti-CD4 $m A b(M T 310)$ and phycoerythrin labelled anti-CD $\mathrm{mAb}$ (DK25). Cells incubated with irrelevant fluorochrome conjugated $m A b s$ served as negative controls and were used to determine the position of quadrant regions.

Table 5 Frequency of subtype non-specific markers in basal lymphoid aggregates of ulcerative colitis colon

\begin{tabular}{lll}
\hline Marker $^{a}$ & Positive cells $(\%)^{b}$ & $n^{c}$ \\
\hline CD45R0 & $52(11)$ & 4 \\
HLA-DR & $46(20)$ & 8 \\
HLA-DQ & $58(6)$ & 3 \\
$\alpha_{\mathrm{E}} \beta_{7}(\mathrm{CD} 103)$ & $26(13)$ & 8 \\
CD28 & $0.1(0.1)$ & 7 \\
bcl-2 & $28(2)$ & 6 \\
\hline
\end{tabular}

${ }^{a}$ The monoclonal antibodies used in the study are shown in table 2.

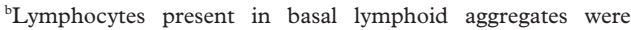
analysed by immunoperoxidase staining and the percentage of positive cells was determined by morphometric analysis according to Weibel and colleagues. ${ }^{28}$

c $n$, number of samples.

$(1.3) \%(n=4)$ of the total LPL were double positive in immunoflow cytometry analysis (fig 4). Although numerous cells expressing the T cell co-receptor CD28 were scattered in lamina propria outside the aggregates (13 (2)\% $\mathrm{CD} 28^{+}$cells $\left.(\mathrm{n}=3)\right)$ no $\mathrm{CD}^{2} 8^{+}$cells were detected in the aggregates (table 5; fig 1D).
There were no significant differences in the frequencies and phenotypes of $\alpha \beta \mathrm{T}$ cell subsets between aggregates in UC colon and solitary follicles in control colon (fig 3).

MOST B CELLS IN THE AGGREGATES EXPRESS IgM ON THEIR SURFACE

The majority of cells in the B cell area of aggregates showed staining by anti-IgM mAb (42 (5) \% IgM $\operatorname{Ig}^{+}$cells $(\mathrm{n}=4)$ ) corresponding to 95 (7) \% of the CD19/20/22 cells. However, no less than 19 (2)\% of the cells in the aggregates expressed $\mathrm{IgA}$ and a small fraction of $\mathrm{IgG}^{+}$cells (3.3 $(0.4) \%(n=4))$ were also detected. These data suggest that $\mathrm{B}$ cells in the aggregates express more than one immunoglobulin isotype and may recently have undergone class switching. No $\mathrm{Ig}^{+}$cells showed cytoplasmic staining, indicating that plasma cells were not present in the aggregates. In contrast, plasma cells were found outside the aggregates.

$\operatorname{IgM}^{+}$cells $(28(2) \%(\mathrm{n}=4))$ outnumbered $\operatorname{IgA}^{+}$cells $(14(1) \%(\mathrm{n}=4))$ and $\mathrm{IgG}^{+}$cells $(2.2$ $(0.4) \%(n=4))$ in the follicles of control colon. However, the sum of $\mathrm{Ig}^{+}$cells equalled the number of CD19/20/22 cells in individual samples. More interestingly, although there was no significant difference in the number of $\mathrm{B}$ cells in follicles compared with aggregates (fig 3), the proportion of surface $\operatorname{IgM}^{+}$cells, surface $\mathrm{IgA}^{+}$cells, and surface $\mathrm{IgG}^{+}$cells was significantly higher in aggregates of UC colon than in follicles of control colon $(\mathrm{p}<0.01$ for all three isotypes).

EXPRESSION OF SUBTYPE NON-RESTRICTED MARKERS IN LYMPHOID AGGREGATES OF UC COLON

Approximately $50 \%$ of cells in the lymphoid aggregates expressed the memory/activation marker CD45R0 (table 5). Moreover, analysis of isolated LPL showed that CD45R0 and CD45RA expressing cells each constituted approximately $50 \%$ of the population $(n=4)$. The majority of $\mathrm{CD}^{+}{ }^{+}$cells expressed CD45R0 but a significant fraction of CD45RA expressing $\mathrm{CD}^{+}$cells were also present (fig 4). The majority of CD45R0 expressing cells were $\mathrm{T}$ cells and $20-40 \%$ of the CD $45 \mathrm{R}^{+}$cells were $\mathrm{B}$ cells. In two samples the sum of CD45R0 and CD45RA expressing cells exceeded 100\% suggesting that cells expressing both splice variants can be present simultaneously.

The majority of MHC class II expressing cells were located in the $\mathrm{B}$ cell area but scattered MHC class II positive cells were seen in the $\mathrm{T}$ cell area (data not shown). The proportion of cells expressing HLA-DR was approximately $50 \%$ (table 5 ). In five samples the number of HLA-DR ${ }^{+}$cells exceeded the number of $\mathrm{B}$ cells, indicating that some $\mathrm{T}$ cells in the aggregates $\left(31-89 \%\right.$ of the $\mathrm{CD}^{+}$cells in these individual samples) also express HLADR. Similar results were obtained with three samples analysed for HLA-DQ expression (table 5).

Interestingly, the integrin $\alpha_{\mathrm{E}} \beta_{7}$, which is present on a large number of IEL in normal gut, was expressed on 26 (13)\% of cells in the aggregates (fig 1C, table 5). Positive cells 


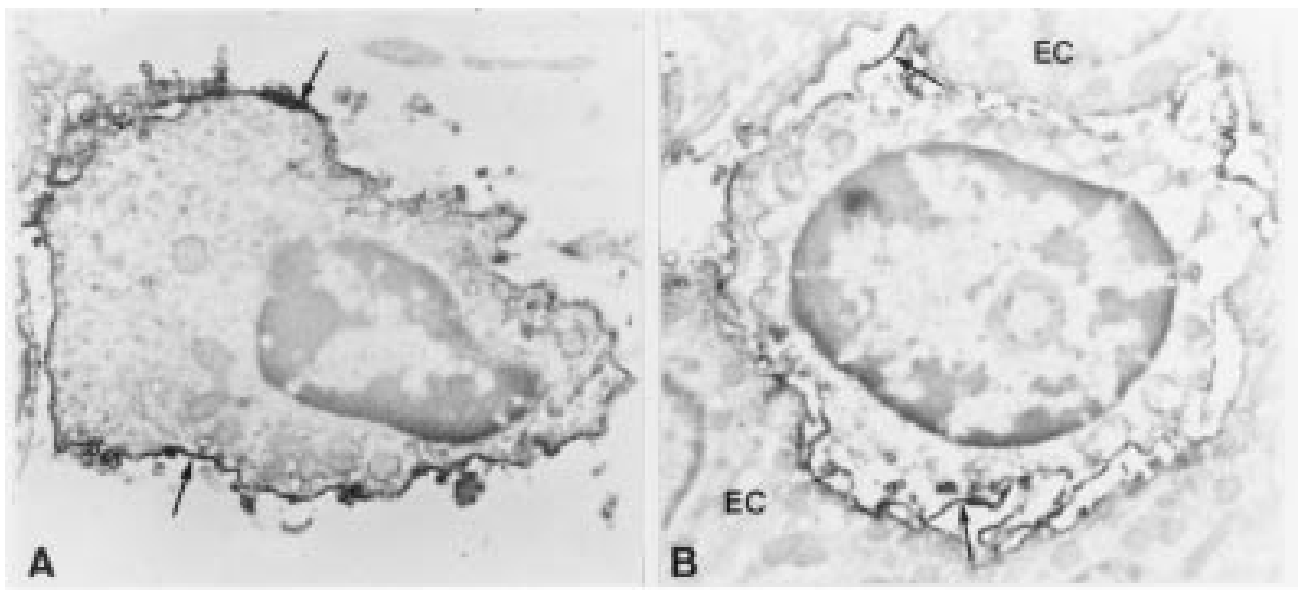

Figure 5 Immunoelectron micrographs of $\gamma \delta$ T lymphocytes in normal colon. (A) A characteristic lamina propria $\gamma \delta T$ cell showing homogeneous surface staining (arrows). (B) An intraepithelial $\gamma \delta T$ cell showing diffuse surface staining (arrows). EC, epithelial cell. All ultrathin sections were examined without additional staining. Original magnification: $A \times 12000 ; B \times 11500$.

showed a heterogeneous distribution, with some areas with many positive cells and other areas with few positive cells. The $\alpha_{\mathrm{E}}$ expressing cells showed variation in the intensity of staining (fig 1C).

One third of lymphocytes in the aggregates expressed the antiapoptotic protein bcl-2 (fig $1 \mathrm{~F}$, table 5). Bcl-2 expressing cells were scattered over the entire aggregate. In normal solitary follicles about $10 \%$ of bcl-2 positive cells were seen. They were all located in the B cell zone.

ULTRASTRUCTURAL ANALYSIS OF $\gamma \delta$ T CELLS IN UC COLON SHOW INTERNALISATION AND SURFACE DOWNREGULATION OF TcR- $\gamma \delta$

The immunoelectron microscopy investigation was focused on $\gamma \delta \mathrm{T}$ cells in UC colon. For comparative purposes we also analysed $\gamma \delta \mathrm{T}$ cells in normal colonic mucosa. TcR- $\gamma \delta$ was detected as deposits of the electron dense reaction product.

In normal colon, the reaction product was homogeneously distributed on the cell surface of all $\gamma \delta \mathrm{T}$ cells found, both on those located in the lamina propria (fig 5A) and on the intraepithelial $\gamma \delta$ T cells (fig 5B).

In contrast, $\gamma \delta$ T cells in UC colon exhibited extreme variability in distribution of the reaction product from cell surface to cytoplasm. We identified five types of staining patterns (five morphotypes). $\gamma \delta \mathrm{T}$ cells of the first type (fig 6A) showed a heterogeneous distribution of the reaction product on the cell surface. Some exhibited single positively stained multivesicular bodies. In $\gamma \delta \mathrm{T}$ cells of the second type, the reaction product was seen as scarce linear clusters more or less randomly distributed over the cell surface (fig 6B). In addition, some clustered deposits were localised over and within surface invaginations that varied from shallow pits to deeper flask-shaped invaginations (fig 6B, inset). It was not possible to use additional counterstaining. Thus although some of the surface invaginations resembled coated pits, we could not determine whether or not these invaginations were coated. In $\gamma \delta \mathrm{T}$ cells of the third type the reaction product was located as cell surface clusters, and also in cytoplasmic vacuoles with morphological characteristics of endosomes (fig 6C). In $\gamma \delta$ T cells of the fourth type the reaction product was abundantly present in the cytoplasm but barely detectable on the cell surface (fig 6D, E, F). The reaction product stained numerous cytoplasmic vesicles and vacuoles near the cell membrane and also deep in the cells close to the nucleus. Positively stained vesicles were sometimes seen in continuity with the plasma membrane and resembled coated vesicles (fig $6 \mathrm{E})$. Numerous multivesicular bodies consisting of tightly packed microvesicles were also stained (fig $6 \mathrm{~F}$ ). $\gamma \delta \mathrm{T}$ cells of the fifth type were rare (fig $6 \mathrm{G}, \mathrm{H}$ ). This morphotype usually showed strong positive staining of the plasma membrane and perinuclear space. Sometimes the reaction product stained diverse cytoplasmic vacuoles of different sizes and shapes. No obvious difference between individual UC colon samples studied was seen.

In summary, the majority of $\gamma \delta \mathrm{T}$ cells (morphotypes 1-4) in UC colon exhibited cellular localisation of the reaction product most probably reflecting the different consecutive steps of TcR internalisation: forming of clusters, coated pits, coated vesicles, endosomes, and multivesicular bodies. ${ }^{30} \mathrm{~A}$ small number of cells (morphotype 5) showed active synthesis of TcR- $\gamma \delta$ molecules.

\section{Discussion}

Our results showed that the lamina propria in UC colon tissue was characterised by a $10-50-$ fold increase in leucocytes compared with normal colon. More than $85 \%$ of leucocytes were lymphocytes and the majority of these lymphocytes were located in the basal lymphoid aggregates consisting of hundreds of densely packed $T$ and $B$ cells. In previous studies of UC colon, surprisingly little attention has been paid to lymphocyte phenotypes in these prominent aggregates. ${ }^{451-34}$ Two intriguing $\mathrm{T}$ cell subsets were present in the aggregates: (i) activated $\gamma \delta \mathrm{T}$ cells using $\mathrm{V} \delta 1$ and (ii) activated $\mathrm{CD}^{+} \alpha \beta \mathrm{T}$ cells lacking the co-stimulatory receptor CD28. 
ORIGIN OF LYMPHOCYTES IN THE AGGREGATES OF UC COLON

Approximately $25 \%$ of lymphocytes in the aggregates expressed the integrin/mucosa lymphocyte marker $\alpha_{\mathrm{E}} \beta_{7}$, suggesting a mucosal ori- gin of a substantial fraction of the $T$ cells in the aggregates. ${ }^{25}{ }^{35}$ Furthermore, the majority of $\gamma \delta$ $\mathrm{T}$ cells in the aggregates used $\mathrm{V} \delta 1$, a feature typical of intraepithelial $\gamma \delta \mathrm{T}$ cells in normal

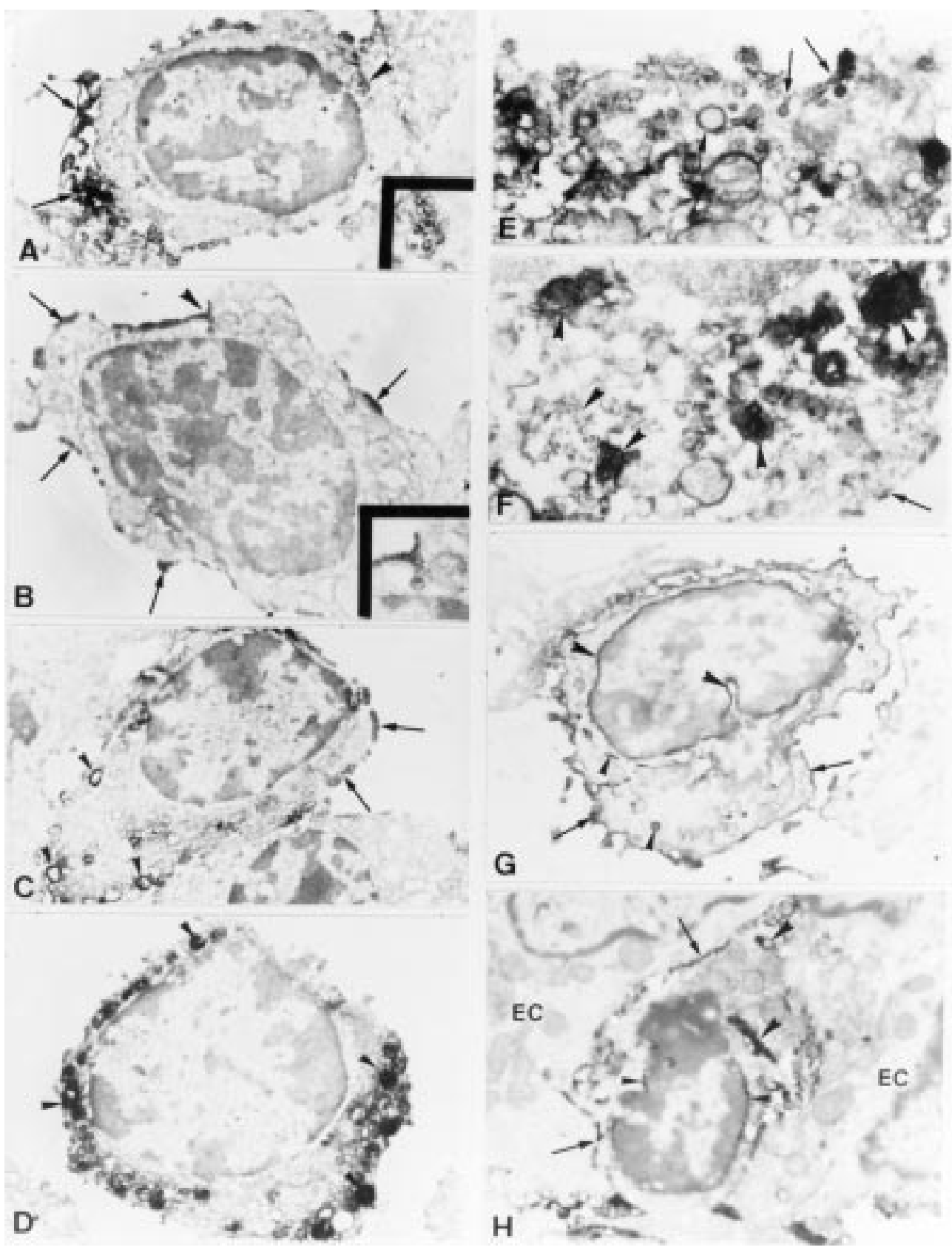

Figure 6 Immunoelectron micrographs of lamina propria $(A-G)$ and intraepithelial $(H) \gamma \delta T$ cells in ulcerative colitis colon. (A) Low power micrograph of a $\gamma \delta$ T lymphocyte with numerous surface processes which are distinctly stained by the reaction product and concentrated at one pole of the cell (arrows). The rest of the cell surface is weakly stained. Inset: High magnification of the positively stained multivesicular body indicated by the arrowhead. (B) $A \gamma \delta T$ cell showing the surface depositions of the reaction product which have the appearance of scarce clusters (arrows). One of the clusters is located over the surface flask-shaped invagination (arrowhead and in the inset at higher magnification). (C) $A \gamma \delta T$ cell displaying the clustered reaction product on the cell surface (arrows) and numerous positively stained cytoplasmic vacuoles near the cell membrane (arrowheads). (D) $A \gamma \delta T$ cell showing only numerous cytoplasmic vesicles and vacuoles of diverse sizes near the cell membrane and deep in the cell. The lumen of these structures exhibit variable intense staining by the reaction product (arrowheads). (E) A portion of the $\gamma \delta T$ cell cytoplasm showing cytoplasmic vesicles that are connected with the plasma membrane and contain the reaction product (arrows). In addition, the cytoplasm contains numerous positively stained vacuoles (arrowheads). (F) A portion of the $\gamma \delta$ T cell cytoplasm showing numerous multivesicular bodies mainly consisting of tightly packed positively stained microvesicles (arrowheads). Arrow depicts a small cluster of the reaction product on the cell surface. (G) $A \gamma \delta$ T lymphocyte showing a strong positive staining of the cell surface (arrows) and the perinuclear space (large arrowheads). Small arrowheads indicate the positive staining of single cytoplasmic vacuoles. (H) $A$ $\gamma \delta$ T lymphocyte showing the positive staining of the cell surface (arrows) and perinuclear space (small arrowheads). Large arrowheads indicate the positively stained cisternal structure in the cytoplasm. EC, epithelial cell. All ultrathin sections were examined without additional staining. Original magnification: $A \times 8600$, inset $\times 25000 ; B \times 9000$, inset $\times 20000 ; C \times 8000$; $D \times 9500 ; E \times 29500 ; F \times 31000 ; G \times 10000 ; H \times 12500$. 
colon, ${ }^{25}$ further indicating an intestinal origin of the lymphocytes in the aggregates.

No CD28 positive cells were present in the aggregates. This implies that none of the $\mathrm{T}$ cell subpopulations present (that is, $\mathrm{CD}^{+} \alpha \beta \mathrm{T}$ cells, $\mathrm{CD}^{+} \alpha \beta$ T cells, and $\gamma \delta \mathrm{T}$ cells) expresses this co-stimulatory molecule. These findings are unexpected as dendritic cells expressing CD80/B7.1 are present in aggregates (this study and Rugtveit and colleagues ${ }^{34}$ ) and interactions between CD28 and CD80/B7.1 are considered essential for induction of $\mathrm{T}$ cell dependent immune responses. ${ }^{37}$ A large fraction of intraepithelial $\mathrm{CD}^{+} \alpha \beta \mathrm{T}$ cells in human small intestine do not express CD28, ${ }^{25}$ and intraepithelial $\mathrm{CD} 8 \alpha \alpha^{+}$and CD4/CD8 double positive $\alpha \beta$ T cells in mice include cells that lack CD28. ${ }^{38}$ Thus it is possible that $\mathrm{CD} 28^{-} \mathrm{CD}^{+} \alpha \beta \mathrm{T}$ cells in aggregates originate from intestinal IEL. It is also likely that CD28 $\gamma \delta \mathrm{T}$ cells in aggregates are of intestinal origin as intraepithelial $\gamma \delta \mathrm{T}$ cells in normal human intestine do not express CD28. ${ }^{25}$ The origin of the $\mathrm{CD} 28^{-} \mathrm{CD} 4^{+} \alpha \beta \mathrm{T}$ cells in the aggregates, and how they acquired this unusual phenotype, are still unknown. It is interesting to note, however, that $\mathrm{CD}^{+} \mathrm{T}$ cells have proved to be important for establishment of colitis in animal models. ${ }^{15} 1739-42$

Histologically, the basal lymphoid aggregates in UC colon resemble the lymphoid follicular hyperplasia described in other types of colitides $^{23}$ and it has been hypothesised that lymphoid follicular hyperplasia is a result of abnormal increases in both the number and size of solitary lymphoid follicles. ${ }^{43}$ Our observations that the basal lymphoid aggregates (i) harbour $\gamma \delta \mathrm{T}$ cells which solitary follicles do not, (ii) have bcl-2 expressing cells scattered throughout, (iii) increase in size but not in number with the severity of disease, (iv) seem to lack true germinal centres with large loosely packed B cells, and (v) contain many $\alpha_{\mathrm{E}} \beta_{7}$ positive cells do not support this hypothesis in the case of UC. The finding that FDC networks were seen in the majority of the UC aggregates is interesting and may be seen as an indication of the similarity between the solitary follicle and UC aggregates. However, it should be noted that many $\mathrm{B}$ cell areas in aggregates lacked FDC networks. Considering all of these findings together we may perhaps best describe the aggregates in UC colon as a consequence of anomalous lymphoid follicular hyperplasia resulting from uncontrolled accumulation of, frequently apoptosis resistant, ${ }^{44}$ mucosal lymphoid cells. Whether they originate from pre-existing follicles or can arise spontaneously anywhere in the lamina propria is still unclear.

MOST LYMPHOCYTES IN AGGREGATES SEEM TO BE ACTIVATED

Firstly, almost all $\gamma \delta \mathrm{T}$ cells and the majority of $\alpha \beta$ T cells expressed the activation/memory cell marker CD45R0. In addition, a significant fraction of the B cells also expressed CD45R0. This supports the findings of Yacyshyn ${ }^{45}$ who reported the presence of activated CD45R0 expressing B cells in UC colon. Secondly, $\gamma \delta \mathrm{T}$ cells, and some $\alpha \beta \mathrm{T}$ cells, had low surface expression of the CD3/TcR complex. The immunoelectron microscopy analysis revealed that most $\gamma \delta \mathrm{T}$ cells exhibited features suggestive of ligand induced $\mathrm{TcR}-\gamma \delta$ downregulation and endocytosis of the CD3/TcR complex, phenomena considered essential in $\mathrm{T}$ cell activation. ${ }^{46}$ Thirdly, approximately one third of lymphocytes had a low density suggesting that they were blasted. ${ }^{47}$ The lymphoblast fraction comprised $\mathrm{B}$ cells and $\mathrm{CD}^{+} \alpha \beta \mathrm{T}$ cells, indicating ongoing $\mathrm{T}$ cell dependent $\mathrm{B}$ cell activation. The low density lymphocyte fraction is lost in standard procedures for isolation of human intestinal lymphocytes and was therefore not reported in previous studies on isolated intestinal lymphocytes in IBD. Finally, a significant fraction of $\mathrm{T}$ cells seemed to express HLA-DR, suggesting activation induced MHC class II expression.

WHAT IS REFLECTED BY DOWNREGULATION OF TCR AT THE SURFACE OF $\gamma \delta$ T CELLS IN UC COLON?

We found that $\mathrm{TcR}-\gamma \delta$ is actively internalised by $\gamma \delta \mathrm{T}$ cells in UC colon and that this internalisation involves a mechanism termed receptor mediated endocytosis. ${ }^{30}$ We also showed that internalisation induced loss of the cell surface TcR- $\gamma \delta$ molecules and accumulation of $\mathrm{TcR}-\gamma \delta$ in the cytoplasmic compartment (that is, downregulation of surface TcR$\gamma \delta)$.

Previous ex vivo experiments demonstrated that TcR $\alpha$ and/or $\beta$ chains are continuously internalised and recycled back to the cell surface. However, $T$ cell stimulation by peptide antigens, superantigens, or anti-TcR antibodies leads to rapid downregulation of surface TcR. TcR downregulation is caused, at least in part, by increased receptor internalisation via the endocytotic pathway, followed by degradation in lysosomes. ${ }^{48}{ }^{49}$ To our knowledge, surface downregulation of $\mathrm{TcR}-\gamma \delta$ caused by its internalisation has not previously been documented in vivo.

Whether TcR internalisation and concomitant surface $\mathrm{TcR}$ downregulation per se are required for $\mathrm{T}$ cell activation remains to be elucidated. Recent reports provided impressive evidence that $\mathrm{T}$ cell activation is correlated with the degree of TcR downregulation and that rapid internalisation of the TcR after contact with antigen is a device to remove triggered TcR molecules from the cell surface. ${ }^{46}{ }^{50}$ Viola and Lanzavecchia ${ }^{50}$ demonstrated that $\mathrm{T}$ cells "count" the number of triggered $\mathrm{TcR}$ and commit themselves to activation only when this number reaches an appropriate threshold. Naturally, the capacity to reach the activation threshold becomes a problem for a cell that has only a few TcR on the surface. Another possibility is that $\mathrm{TcR}$ downregulation does not necessarily lead to $\mathrm{T}$ cell activation but is a key mechanism involved in tuning $\mathrm{T}$ cell function for extinction and calibration of $T c R$ signalling. ${ }^{51}{ }^{52}$ As $\mathrm{TcR}$ downregulation is most prominent with high affinity agonistic ligands, internalisation of $\mathrm{TcR}$ could be a protective measure to control the extent of $\mathrm{T}$ cell activation. ${ }^{48}$ 
The biological consequences of surface $\mathrm{TcR}-\gamma \delta$ downregulation may be both physiological and pathological. On the one hand, $\gamma \delta$ $T$ cells with selective downregulation of surface $\mathrm{TcR}$ have been described in human pregnancy decidua. ${ }^{534}$ In this case, downregulation of $\mathrm{TcR}-\gamma \delta$ may contribute towards creation of transient unresponsiveness to paternal antigens and to a successful outcome of pregnancy. Interestingly, decidual $\gamma \delta \mathrm{T}$ cells did not show active internalisation of $\mathrm{TcR}$ indicating that internalisation is not the only mechanism of $\mathrm{TcR}$ downregulation.

On the other hand, recent experiments have shown that altered peptides (partial agonistic/ antagonistic) also trigger $\mathrm{TcR}$ internalisation, and alter differentiation and effector functions of the responding $\mathrm{T}$ lymphocytes. ${ }^{55}$ Thus it is possible that in UC colon a few, possibly altered, peptides permanently engage and downregulate the number of $\mathrm{TcR}-\gamma \delta$, dramatically reducing the number of $\mathrm{TcR}$ that are available for physiological agonistic ligands. This could result in alterations of the immunoregulatory functions of $\gamma \delta \mathrm{T}$ cells and, consequently, an abnormal mucosal immune response to enteric antigens.

POSSIBLE ROLES FOR $\gamma \delta$ T CELLS IN UC COLON In contrast with the normal colon, numerous $\gamma \delta \mathrm{T}$ cells were present mainly in the lamina propria in the lymphoid aggregates but also as scattered single cells in the lamina propria outside the aggregates and in the submucosa. $\gamma \delta \mathrm{T}$ cells in UC colon have been observed previously ${ }^{31}$ but that study focused on scattered $\gamma \delta \mathrm{T}$ cells with strong surface staining (morphotype 5) which constitute only a small cell population. Increased numbers of $\gamma \delta \mathrm{T}$ cells in peripheral blood from IBD patients has also been reported. ${ }^{56}$

Previous studies have suggested a role for $\mathrm{V} \delta 1^{+}$cells in the pathogenesis of inflammatory diseases. $\mathrm{V} \delta 1^{+}$cells were reported to be present in the intestinal mucosa of IBD patients,${ }^{57-59}$ the synovial tissue of patients with rheumatoid arthritis, ${ }^{60}$ and the epithelium of chronically inflamed parodontitis gingiva. ${ }^{26}$ The number of intraepithelial $\mathrm{V} \delta 1^{+}$cells is elevated in active coeliac disease. ${ }^{61}$ Similarly, ${\mathrm{V} \delta 1^{+}}^{+}$cells agglomerate in skin lesions of patients with leprosy and leishmaniasis. ${ }^{62} 63$ $\mathrm{V} \delta 1^{+}$cells can be cytotoxic against tumour cells of epithelial origin, ${ }^{64}$ and can recognise stress induced molecules. ${ }^{65}$ Aberrant immune responses causing formation of aggregates with stressed $\mathrm{B}$ and $\alpha \beta \mathrm{T}$ cells could be responsible for the observed increase in numbers of $\mathrm{V} \delta 1^{+}$cells in UC colon.

Stressed malfunctioning $\alpha \beta \mathrm{T}$ cells are likely to develop during chronic inflammation. In this case they may be replaced by $\gamma \delta \mathrm{T}$ cells. $\gamma \delta \mathrm{T}$ cells can act as $\mathrm{T}$ helper cells to support antibody production and in the formation of germinal centres in $\alpha \beta \mathrm{T}$ cell deficient mice. ${ }^{66}$ However, these $\alpha \beta \mathrm{T}$ cell deficient mice have high levels of autoreactive IgG antibodies. ${ }^{66}{ }^{67}$ Mice with Listeria monocytogenes infected kidneys develop an inflammatory disease with autoimmune traits. ${ }^{68}$ In these mice $\gamma \delta \mathrm{T}$ cells are recruited to the site of inflammation subsequent to $\alpha \beta \mathrm{T}$ cells. It is possible, therefore, that $\gamma \delta \mathrm{T}$ cells target the aggregates of UC colon as a response to the presence of stressed lymphocytes initially activated by infection in the colonic mucosa. Once in the aggregate, the $\gamma \delta$ $\mathrm{T}$ cells may influence the development of $\mathrm{B}$ cells and in this way be responsible for the increased production of autoantibodies noted in UC colon. ${ }^{7} 101113$

This work was supported by grants from the Swedish Natural Science Research Council (grant No B-AA/BU 11234-300, M-LH), the Swedish Medical Research Council (grant No 19x11240, ÅD; K200-71, SH), the Swedish Cancer Foundation (SH) the County of Västerbotten (SH and ÅD), Bengt Ihreís Foundation (ÅD), and the Swedish Labour Market Insurance Company, AFA (SH). The skilful technical assistance of Elisabeth Granström and Marianne Sjöstedt is gratefully acknowledged.

1 Kozarek RA. Review article: immunosuppressive therapy for inflammatory bowel disease. Aliment Pharmacol Ther 1993;7:117-23.

2 Löfberg R, Danielsson Å, Suhr O, et al. Oral budesonide versus prednisolone in patients with active extensive and versus prednisolone in patients with active extensive and
left-sided ulcerative colitis. Gastroenterology 1996;110: left-sided 18.

3 Lichtiger S, Present DH, Kornbluth A, et al. Cyclosporine in severe ulcerative colitis refractory to steroid therapy. $N$ Engl F Med 1994;330:1841-5.

4 Beagley KW, Elson CO. Cells and cytokines in mucosal immunity and inflammation. Gastroenterol Clin North Am 1992;21:347-66.

5 Schreiber S, Raedler A, Stenson WF, et al. The role of the mucosal immune system in inflammatory bowel disease. Gastroenterol Clin North Am 1992;21:451-502.

6 Broberger O, Perlmann P. Autoantibodies in ulcerative colitis. F Exp Med 1959;110:657-74.

7 Lagercrantz R, Hammarström S, Perlmann $\mathrm{P}$, et al. Immunological studies in ulcerative colitis. IV. Origin of Immunological studies in ulcerative colitis. IV.

8 Duchmann R, Kaiser I, Hermann E, et al. Tolerance exists towards resident intestinal flora but is broken in active inflammatory bowel disease. Clin Exp Immunol 1995;102: inflamm $448-55$.

9 Das KM, Dasgupta A, Mandal A, et al. Autoimmunity to cytoskeletal protein tropomyosin. A clue to the pathogenic mechanism for ulcerative colitis. F Immunol 1993;150: 2487-93.

10 Takahashi F, Das KM. Isolation and characterisation of a colonic autoantigen specifically recognised by colon tissue bound immunoglobulin $\mathrm{G}$ from idiopathic ulcerative colitis. F Clin Invest 1985;76:311-18

11 Targan SR, Landers CJ, Cobb L, et al. Perinuclear anti-neutrophil cytoplasmic antibodies are spontaneously produced by mucosal B cells of ulcerative colitis patients. $\mathcal{F}$ Immunol 1995;155:3262-7.

12 Macpherson A, Khoo UY, Forgacs I, et al. Mucosal antibodies in inflammatory bowel disease are directed antibodies in inflammatory bowel disease are

13 Halstensen TS, Mollnes TE, Garred P, et al. Epithelial deposition of immunoglobulin G1 and activated complement (C3b and terminal complement complex) in ulcerative colitis. Gastroenterology 1990;98:1264-71.

14 Mombaerts P, Mizoguchi E, Grusby MJ, et al. Spontaneous development of inflammatory bowel disease in $\mathrm{T}$ cell receptor mutant mice. Cell 1993;75:275-82.

15 Holländer GA, Simpson SJ, Mizoguchi E, et al. Severe colitis in mice with aberrant thymic selection. Immunity 1995; 3:27-38.

16 Sadlack B, Merz H, Schorle H, et al. Ulcerative colitis-like disease in mice with a disrupted interleukin-2 gene. Cell 1993;75:253-61

17 Kühn R, Löhler J, Rennick D, et al. Interleukin-10-deficient mice develop chronic enterocolitis. Cell 1993;75:263-74.

18 Shull MM, Ormsby I, Kier AB, et al. Target disruption of the mouse transforming growth factor- $\beta 1$ gene results in the mouse transforming growth factor- $\beta 1$ gene results in
multifocal inflammatory disease. Nature 1992;359:693-9.

19 Rudolph U, Finegold MJ, Rich SS, et al. Ulcerative colitis Rudolph U, Finegold MJ, Rich SS, et al. Ulcerative colitis
and adenocarcinoma of the colon in G alpha i2-deficient mice. Nat Genet 1995;10:143-50.

20 Surawisz CM, Belic L. Rectal biopsy helps to distinguish acute self-limited colitis from idiopathic inflammatory bowel disease. Gastroenterology 1984;86:104-13.

21 Odze R, Antonioli D, Peppercorn M, et al. Effect of topical 5 -aminosalicylic acid (5-ASA) therapy on rectal mucosal biopsy morphology in chronic ulcerative colitis. Am F Surg Pathol 1993;17:869-75.

22 Surawisz CM, Haggitt RC, Husseman M, et al. Mucosal biopsy diagnosis of colitis: acute self-limited colitis and idiopathic inflammatory bowel disease. Gastroenterology 1994; 107:755-63.

23 Haque S, Eisen RN, West AB. The morphologic features of diversion colitis: studies of a pediatric population with no other disease of the intestinal mucosa. Hum Pathol 1993;24:211-19. 
24 Lundqvist C, Hammarström M-L, Athlin L, et al. Isolation of functionally active intraepithelial lymphocytes and enterocytes from human smal
Methods 1992;152:253-63.

25 Lundqvist C, Baranov V, Hammarström S, et al. Intraepithelial lymphocytes. Evidence for regional specialization and extrathymic T cell maturation. Int Immunol 1995; 1473-87.

26 Lundqvist C, Hammarström M-L. T cell receptor $\gamma \delta$ expressing intraepithelial lymphocytes are present in normal and chronically inflamed human gingiva. Immunology 1993;79:38-45.

27 Pileri SA, Roncador G, Ceccarelli C, et al. Antigen retrieval techniques in immunohistochemistry: Comparison of different methods. F Pathol 1997;183:116-23.

28 Weibel ER, Kistler GS, Scherle WF. Practical stereological methods for morphometric cytology. F Cell Biol 1966;30: 23-38.

29 Nagashima R, Maeda K, Imai Y, et al. Lamina propria macrophages in the human gastrointestinal mucosa: Their disrophages in the human gastrointestinal mucosa: Their distribution, immunological phenotyp
chem Cytochem 1996;44:721-31.

30 Gruenberg J, Maxfield F. Membrane transport in the endocytic pathway. Curr Opin Cell Biol 1995;7:552-63.

31 Fukushima K, Masuda T, Ohtani H, et al. Immunohistochemical characterization, distribution, and ultrastructure of lymphocytes bearing T cell receptor $\gamma / \delta$ in inflammatory bowel disease. Gastroenterology 1991;101:670-8.

32 Hirata I, Berrebi G, Austin LL, et al. Immunohistological characterization of intraepithelial and lamina propria lymphocytes in control ileum and colon and in inflammatory bowel disease. Dig Dis Sci 1986;31:593-603.

33 Arato A, Savilathi E, Tainio V-M, et al. Immunohistochemical study of lymphoplasmacytic infiltrate and epithelial HLA-DR expression in the rectal and colonic mucosae of children with ulcerative colitis. $\mathcal{F}$ Pedriatr Gastroenterol Nutr 1989;8:172-80.

34 Rugtveit J, Bakka A, Brandtzaeg P. Differential distribution of B7.1(CD80) and B7.2(CD86) costimulatory molecules of B7.1(CD80) and B7.2(CD86) costimulatory molecules bowel disease. Clin Exp Immunol 1997;110:104-13.

35 Jarry A, Cerf-Bensussan N, Brousse N, et al. Subsets of $\mathrm{CD}^{+}\left(\mathrm{T}\right.$ cell receptor $\alpha / \beta$ or $\gamma / \delta$ ) and $\mathrm{CD} 3^{-}$lymphocytes isolated from normal human gut epithelium display phenotypical features different from their counterparts in human blood. Eur F Immunol 1990;20:1097-103.

36 Deusch K, Lüling F, Reich K, et al. A major fraction of human intraepithelial lymphocytes simultaneously express the $\gamma / \delta \mathrm{T}$ cell receptor, the CD8 molecule and preferentially uses the $\mathrm{V} \delta 1$ gene segment. Eur $\mathcal{F}$ Immunol 1991;21: 1053-9.

37 Lindsten T, June CH, Ledbetter JA, et al. Regulation of lymphokine messenger RNA stability by a surface-mediated T-cell activation pathway. Science 1989;244:339-43.

38 Ohteki T, MacDonald HR. Expression of the CD28 costimulatory molecule on subsets of murine intestinal intraepithelial lymphocytes correlates with lineage and responsiveness. Eur f Immunol 1993;23:1251-5.

responsiveness. Eur F Immunol 1993;23:1251-5.
39 Powrie F, Leach MW, Mauze S, et al. Phenotypically distinct subsets of CD4 $4^{+} \mathrm{T}$ cells induce or protect from chronic subsets of $\mathrm{CD}^{+} \mathrm{T}$ cells induce or protect from chronic intestinal inflammat

40 Simpson SJ, Mizoguchi E, Allen D, et al. Evidence that $\mathrm{CD} 4^{+}$, but not $\mathrm{CD}^{+} \mathrm{T}$ cells are responsible for the murine interleukin-2-deficient colitis. Eur f Immunol 1995;25 2618-25.

41 Morrisey PJ, Charrier K, Braddy S, et al. $\mathrm{CD}^{+} \mathrm{T}$ cells that express high levels of CD45RB induce wasting disease when transferred into congenic severe combined immunodeficient mice: disease development is prevented by cotransfer of purified CD4 ${ }^{+} \mathrm{T}$ cells. 7 Exp Med 1993;178: 237-44.

42 Cong Y, Brandwein SL, McCabe RP, et al. $\mathrm{CD} 4^{+} \mathrm{T}$ cells reactive to enteric bacterial antigens in spontaneously colitic $\mathrm{C} 3 \mathrm{H} / \mathrm{HeJBir}$ mice: increased $\mathrm{T}$ helper cell type 1 response and ability to transfer disease. $f$ Exp Med response and a

43 O'Leary AD, Sweeney EC. Lymphoglandular complexes of the colon: structure and distribution. Histopathology 1986 10:267-83.

44 Cory S. Regulation of lymphocyte survival by the bcl-2 gene family. Ann Rev Immunol 1995;13:513-43.

45 Yacyshyn BR. Activated $\mathrm{CD} 19^{+} \mathrm{B}$ cell lamina propria lymphocytes in ulcerative colitis. Immunol Cell Biol 1993;71:265-74
46 Valitutti S, Müller S, Cella M, et al. Serial triggering of many T-cell receptors by a few peptide-MHC complexes. Nature 1995:375:148-51.

47 Hutchins D, Steel CM. Separation of human lymphocytes on the basis of volume and density. In: Peeters H, ed. Separation of cells and subcellular elements. Oxford and New York: Pergamon Press, 1979:77-82.

48 Valitutti S, Müller S, Salio M, et al. Degradation of T cell receptor (TCR)-CD3-zeta complexes after antigenic stimulation. F Exp Med 1997;185:1859-64.

49 Niedergang F, Dautry-Varsat A, Alcover A. Peptide antigen or superantigen-induced down-regulation of TcRs involves both stimulated and unstimulated receptors. F Immunol 1997;159:1703-10.

50 Viola A, Lanzavecchia A. T cell activation determined by $\mathrm{T}$ cell receptor number and tuneable thresholds. Science 1996;273:104-6.

51 Cai Z, Kishimoto H, Brunmark A, et al. Requirements for peptide-induced $\mathrm{T}$ cell receptor downregulation on naive CD ${ }^{+}$T cells. F Exp Med 1997;185:641-51.

52 Salio M, Valitutti S, Lanzavecchia A. Agonist-induced T cell receptor down-regulation: molecular requirements and dissociation from T cell activation. Eur F Immunol 1997;27: 1769-73.

53 Mincheva-Nilsson L, Hammarström S, Hammarström M-L. Human decidual leukocytes from early pregnancy contain high numbers of $\gamma \delta^{+}$cells and show selective downregulation of alloreactivity. F Immunol 1992;149:2203-11.
Mincheva-Nilsson L, Kling M, Hammarström S, et al. $\gamma \delta$ T 54 Mincheva-Nilsson L, Kling M, Hammarström S, et al. $\gamma \delta \mathrm{T}$
cells of human early pregnancy decidua. Evidence for local proliferation, phenotypic heterogeneity, and extrathymic differentiation. F Immunol 1997;159:3266-77.

55 Germain R, Levine E, Madrenas J. The T-cell receptor as a diverse signal transduction machine. Immunologist 1995;3: 113-21.

56 Giacomelli R, Parzanese I, Frieri G, et al. Increase of circulating $\gamma / \delta$ T lymphocytes in the peripheral blood of patients affected by active inflammatory bowel disease. Clin Exp affected by active inflan

57 Bucht A, Söderström K, Esin S, et al. Analysis of $\gamma \delta \mathrm{V}$ region usage in normal and diseased human intestinal biopsies and peripheral blood by polymerase chain reaction (PCR) and flow cytometry. Clin Exp Immunol 1995;99:57-64.

58 McVay LD, Li B, Biancaniello R, et al. Changes in human mucosal gamma delta $\mathrm{T}$ cell repertoire and function associated with the disease process in inflammatory bowel disease. Mol Med 1997; 3:183-203.

59 Trejdosiewicz LK, Calabrese A, Smart CJ, et al. $\gamma \delta \mathrm{T}$ cell receptor-positive cells of the human gastrointestinal mucosa: occurrence and $\mathrm{V}$ region gene expression in Helicobacter pylori -associated gastritis, coeliac disease and inflammatory bowel disease. Clin Exp Immunol 1991;84: inflamm $440-4$.

60 Söderström K, Halapi E, Nilsson E, et al. Synovial cells responding to a $65 \mathrm{kD}$ mycobacterial heat shock protein have a high proportion of a TcR $\gamma / \delta$ subtype uncommon in peripheral blood. Scand f Immunol 1990;32:503-15.

61 Halstensen TS, Scott H, Brandtzaeg P. Intraepithelial T cells of the $\mathrm{TcR} \gamma / \delta^{+} \mathrm{CD} 8^{-}$and $\mathrm{V} \delta 1 / \mathrm{J} \delta 1^{+}$phenotypes are increas

62 Uyemura K, Ho CT, Ohmen JD, et al. Selective expansion of $\mathrm{V} \delta 1^{+} \mathrm{T}$ cells from leprosy skin lesions. $\mathcal{F}$ Invest Dermatol 1992;99:848-52.

63 Uyemura K, Klotz J, Pirmez C, et al. Microanatomic clonality of $\gamma \delta \mathrm{T}$ cells in human leishmaniasis lesions. F Immunol 1992:148:1205-11.

64 Maeurer MJ, Martin D, Walter W, et al. Human intestinal $\mathrm{V} \delta 1^{+} \mathrm{T}$ lymphocytes recognize tumor cells of epithelial origin. F Exp Med 1996;183:1681-96.

65 Groh V, Steinle A, Bauer S, et al. Recognition of stress-induced MHC molecules by intestinal epithelial $\gamma \delta$ T cells. Science 1998;279:1737-40.

66 Wien BL, Pao W, Wong FS, et al. Germinal center formation, immunoglobulin class switching, and autoantibody production driven by "non $\alpha / \beta$ " T cells. $\mathcal{F}$ Exp Med 1996;183:2271-82.

67 Wen L, Roberts SJ, Viney JL, et al. Immunoglobulin synthesis and generalized autoimmunity in mice congenitally deficient in $\alpha \beta(+)$ T cells. Nature 1994;369:654-8.

68 Sonoda K, Mukasa A, Matsuzaki G, et al. The induction of renal autoantigen-specific $\mathrm{T}$ cells by a local Listeria monocytogenes infection. Immunology 1995;86:90-8. 